\title{
Long-term study of VOCs measured with PTR-MS at a rural site in New Hampshire with urban influences
}

\author{
C. Jordan, E. Fitz, T. Hagan, B. Sive, E. Frinak, K. Haase, L. Cottrell, S. Buckley, and R. Talbot \\ Climate Change Research Center, Institute for the Study of Earth, Oceans, and Space, University of New Hampshire, \\ Durham, NH, 03824, USA
}

Received: 20 November 2008 - Published in Atmos. Chem. Phys. Discuss.: 10 February 2009

Revised: 12 June 2009 - Accepted: 2 July 2009 - Published: 17 July 2009

\begin{abstract}
A long-term, high time-resolution volatile organic compound (VOC) data set from a ground site that experiences urban, rural, and marine influences in the Northeastern United States is presented. A proton-transfer-reaction mass spectrometer (PTR-MS) was used to quantify 15 VOCs: a marine tracer dimethyl sulfide (DMS), a biomass burning tracer acetonitrile, biogenic compounds (monoterpenes, isoprene), oxygenated VOCs (OVOCs: methyl vinyl ketone (MVK) plus methacrolein (MACR), methanol, acetone, methyl ethyl ketone (MEK), acetaldehyde, and acetic acid), and aromatic compounds (benzene, toluene, $\mathrm{C}_{8}$ and $\mathrm{C}_{9}$ aromatics). Time series, overall and seasonal medians, with 10th and 90th percentiles, seasonal mean diurnal profiles, and inter-annual comparisons of mean summer and winter diurnal profiles are shown. Methanol and acetone exhibit the highest overall median mixing ratios 1.44 and 1.02 ppbv, respectively. Comparing the mean diurnal profiles of less well understood compounds (e.g., MEK) with better known compounds (e.g., isoprene, monoterpenes, and MVK + MACR) that undergo various controls on their atmospheric mixing ratios provides insight into possible sources of the lesser known compounds. The constant diurnal value of $\sim 0.7$ for the toluene:benzene ratio in winter, may possibly indicate the influence of wood-based heating systems in this region. Methanol exhibits an initial early morning release in summer unlike any other OVOC (or isoprene) and a dramatic late afternoon mixing ratio increase in spring. Although several of the OVOCs appear to have biogenic sources, differences in features observed between isoprene, methanol, acetone, acetaldehyde, and MEK suggest they are produced or emitted in unique ways.
\end{abstract}

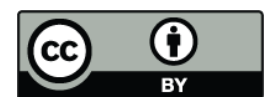

Correspondence to: C. Jordan (carolyn.jordan@unh.edu)

\section{Introduction}

Volatile organic compounds (VOCs) are emitted into the atmosphere from both natural and anthropogenic sources and have lifetimes ranging from minutes to months. This diverse group of compounds is of interest in the troposphere because of their role in ozone $\left(\mathrm{O}_{3}\right)$ production, aerosol formation and controls on regional air quality. While long-term records of VOCs exist (e.g., Penkett et al., 1993; Jobson et al., 1994; Goldstein et al., 1995; Thijsse et al., 1999; Solberg et al., 2001; Gautrois et al., 2003; Yang et al., 2005; Reiss, 2006; Simmonds et al., 2006; Lee et al., 2006; Qin et al., 2007; Sive et al., 2007; Nguyen et al., 2009), the measurements rely on conventional methods such as gas chromatography with hourly time resolution at best. Although these records provide a wealth of information, proton transfer reaction-mass spectrometry (PTR-MS) offers greatly improved time resolution. However, the current literature has little to offer in terms of seasonal comparisons based on this technique (Schade and Goldstein, 2006; Filella and Peñuelas, 2006) and is devoid of inter-annual comparisons.

A PTR-MS was used to quantify a suite of VOCs at Thompson Farm in southeastern New Hampshire, from 24 July to 31 August 2004 and from 1 June 2005 to 31 May 2008. The results presented here encompass four summers, and three falls, winters and springs. The summary provided here terminates 31 May 2008, but these measurements are ongoing. These data are available upon request. This longterm data set permits inter-annual comparisons and defines seasonal and diurnal characteristics of the analytes at a midlatitude site.

The compounds reported here (Table 1) broadly fall into three categories: biogenic (monoterpenes, isoprene and its oxidation products methyl vinyl ketone (MVK) and methacrolein (MACR)), oxygenated VOCs (OVOCs: methanol, acetone, methyl ethyl ketone (MEK), acetaldehyde, and acetic acid), and aromatic (benzene, toluene, $\mathrm{C}_{8}$

Published by Copernicus Publications on behalf of the European Geosciences Union. 
Table 1. List of reported compounds along with their protonated $\mathrm{m} / \mathrm{z}$, limits of detection (LOD), and type as discussed in the text.

\begin{tabular}{lrll}
\hline Compound & Protonated $\mathrm{m} / \mathrm{z}$ & LOD $(\mathrm{ppb})$ & Group \\
\hline Methanol & 33 & 0.240 & Oxygenated \\
Acetonitrile & 42 & 0.020 & Biomass Burning \\
Acetaldehyde & 45 & 0.050 & Oxygenated \\
Acetone & 59 & 0.020 & Oxygenated \\
Acetic Acid & 61 & 0.080 & Oxygenated \\
DMS & 63 & 0.025 & Marine Tracer \\
Isoprene & 69 & 0.020 & Biogenic \\
Methyl vinyl ketone (MVK) & 71 & 0.020 & Oxygenated \\
Methacrolein (MACR) & 71 & 0.020 & Oxygenated \\
Methyl ethyl ketone (MEK) & 73 & 0.015 & Oxygenated \\
Benzene & 79 & 0.020 & Aromatic \\
Toluene & 93 & 0.015 & Aromatic \\
C $_{8}$ Aromatics & 107 & 0.025 & Aromatic \\
C 9 Aromatics & 121 & 0.025 & Aromatic \\
Monoterpenes & 137 & 0.050 & Biogenic \\
\hline
\end{tabular}

and $\mathrm{C}_{9}$ aromatics). In addition, dimethyl sulfide (DMS) released by phytoplankton (Bates et al., 1992) in the Gulf of Maine is a marine tracer, while acetonitrile is a biomass burning tracer (Lobert et al., 1990; Holzinger et al., 1999; Bange and Williams, 2000). The complete time series are presented here, along with median annual and seasonal mixing ratios, mean diurnal characteristics of the data, and interannual variability of the mean diurnal cycles in summer and winter.

\section{Methods}

\subsection{Field site description}

The University of New Hampshire Observing Station at Thompson Farm $(\mathrm{TF})\left(43.11^{\circ} \mathrm{N}, 70.95^{\circ} \mathrm{W}\right.$, elevation $\left.24 \mathrm{~m}\right)$ is located in Durham, a rural area in southeastern New Hampshire (Fig. 1). TF is $24 \mathrm{~km}$ from the Gulf of Maine and $5 \mathrm{~km}$ northwest of Great Bay, $\mathrm{NH}$, and is located on an active corn (through 2005) and alfalfa (2006 to present) farm surrounded by a mixed forest. Located near the coasts of Maine and New Hampshire, TF is a unique sampling location, where air masses that have been influenced by a variety of different source regions, including coastal marine, the forested sub-Arctic, the industrialized Midwestern US, the metropolitan East coast and the open North Atlantic Ocean, are periodically encountered.

Ambient air at TF is analyzed onsite for numerous species including $\mathrm{CO}, \mathrm{O}_{3}, \mathrm{SO}_{2}$, $\mathrm{NO}$ and $\mathrm{NO}_{y}$, as well as VOCs. Additionally, meteorological parameters such as wind speed, wind direction and temperature are also monitored. Details and a record of these measurements are reported at the AIRMAP website (http://airmap.unh.edu/).

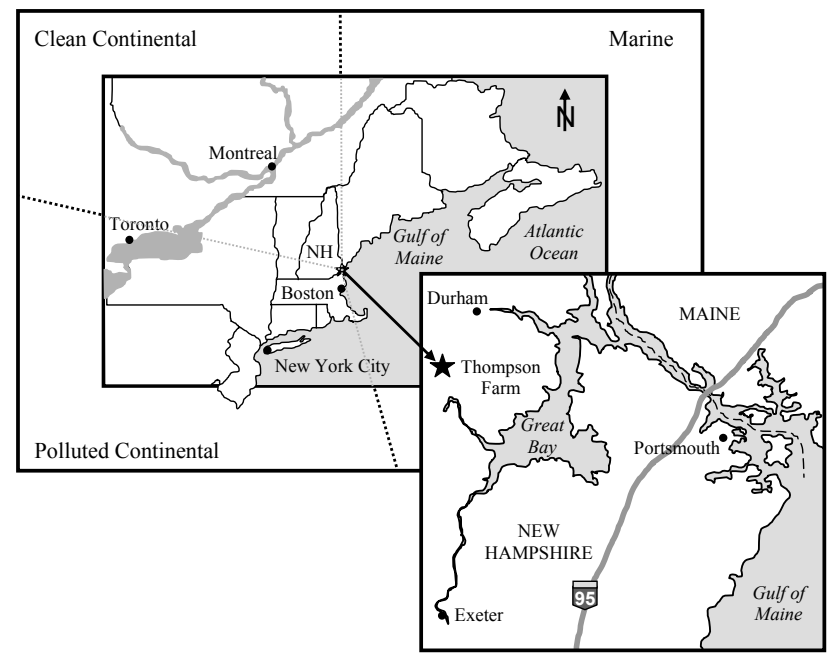

Fig. 1. Thompson Farm (TF) in Durham, NH is located in New England region of United States. This location is influenced by polluted continental air masses from the south and west, clean continental air masses from the north, and marine air masses from the east (main map). TF is located approximately $20 \mathrm{~km}$ west of Portsmouth on the sea coast of $\mathrm{NH}$ and the Interstate 95 corridor (inset).

\subsection{Instrument operation}

A PTR-MS obtained from Ionicon Analytik, Innsbruck, Austria was used for high frequency measurements of several groups of non-methane hydrocarbons (NMHCs), certain individual OVOCs, DMS, and acetonitrile at TF (Table 1). PTR-MS employs chemical ionization by reaction of $\mathrm{H}_{3} \mathrm{O}^{+}$ reagent ions for soft ionization of gas phase compounds having a proton affinity greater than that of water; ionization occurs via proton transfer from the $\mathrm{H}_{3} \mathrm{O}^{+}$and the resulting ion is detected using a quadrupole mass spectrometer (Lindinger et al., 1998). The instrument and its operation have been described in great detail in a recent review (de Gouw and Warneke, 2007) and will not be described here further. Specifics on the operational parameters of the PTRMS at TF may be found in Talbot et al. (2005) and Ambrose et al. (2007).

The PTR-MS sampled ambient air that was continuously drawn down a PFA Teflon-lined manifold from the top of a $12 \mathrm{~m}$ tower (Talbot et al., 2005). A sub-stream of air off the main sample line was sent directly to the PTR-MS at 1000 standard cubic centimeters per minute. The PTR-MS was operated with the drift tube set to an E/N of 140 Townsend while continuously stepping through a series of $30 \mathrm{~m} / \mathrm{z}$ channels. Of the 30 channels monitored, 6 were used for diagnostic purposes while the other 24 corresponded to the VOCs of interest. The dwell time for each of the 24 channels ranged from 2-20 s, yielding a total measurement cycle of $\sim 6 \mathrm{~min}$.

The background signal was obtained every $2.5 \mathrm{~h}$ through 2006 and then every $12 \mathrm{~h}$ from 2006-present because of the 
system stability. The system is zeroed for 4 cycles by diverting the flow of ambient air through a heated catalytic converter $\left(0.5 \% \mathrm{Pd}\right.$ on alumina at $\left.450^{\circ} \mathrm{C}\right)$ to oxidize the VOCs and determine system background signals (Talbot et al., 2005; Ambrose et al., 2007). Following a linear interpolation, the background was subtracted from the ambient signal. Ambient mixing ratios for most species were then determined by converting the raw PTR-MS signal in $\mathrm{Hz}$ to mixing ratio in ppbv or parts per trillion by volume (pptv) using experimentally determined calibration factors. Limits of detection (LOD) were determined based on a signal to noise ratio of 2 as described by Karl et al. (2003) and are reported in Table 1.

Calibrations for the PTR-MS system were conducted using three different high-pressure cylinders containing synthetic blends of selected NMHCs, OVOCs and acetonitrile at the part per billion by volume (ppbv) level (Apel-Riemer Environmental, Inc., Denver, CO). Each of the cylinders used in the calibrations had an absolute accuracy of $< \pm 5 \%$ for all gases. Using methods similar to those described by Apel et al. (1998), standards were diluted to atmospheric mixing ratios (ppbv to pptv levels) with catalytic converter prepared zero air adjusted to maintain the humidity of the sampled air. Calibrations were conducted periodically (manual calibrations were performed seasonally in 2004, 2005, and 2006 (ranging from every 4 to 12 weeks), daily single point calibrations and bi-weekly multi-point calibrations began in July 2007) to monitor PTR-MS performance, quantify the mixing ratios of target gases and to confirm calibration factors.

Acetic acid calibration factors were determined using a permeation calibration system similar to that described in Talbot et al. (1999) and tubes obtained from Kin-Tek Laboratories, Inc. (La Marque, TX). A dilution flow of VOC-free air, generated by passing ambient air through the catalytic converter, was used to dilute and vary the acetic acid mixing ratios to construct a multipoint calibration curve.

DMS mixing ratios were calculated based on the ionmolecule reaction kinetics of the reagent gas and the ion transmission through the quadrupole. To verify the accuracy of the calculated DMS mixing ratios, inter-calibrations were conducted using both canister samples and an automated in situ gas chromatographic system (Sive et al., 2005) using whole air standards from D. Blake (University of California, Irvine).

Table 1 lists the 15 compounds/groups of compounds of interest to this study and their corresponding protonated $\mathrm{m} / \mathrm{z}$ measured by PTR-MS. Several isobaric species should be noted: mixing ratios reported for $\mathrm{m} / \mathrm{z} 71$ are the sum of MVK and MACR; m/z 107 includes, among others, the three isomers of xylene and ethylbenzene and is collectively referred to as $\mathrm{C}_{8}$ aromatics. Similarly, $\mathrm{m} / \mathrm{z} 121$ includes the trimethylbenzenes and propylbenzenes and is summarized as $\mathrm{C}_{9}$ aromatics. Finally, total monoterpenes are measured at m/z 137; for most monoterpenes $>99 \%$ of the signal can be attributed to the $\mathrm{C}_{10} \mathrm{H}_{16} \mathrm{H}^{+}$ion (Tani et al., 2003; Lee et al., 2005).
From 24 July 2004 until 8 November 2005, measurements were conducted at TF using a standard sensitivity PTR-MS, after which time it was replaced with a high sensitivity PTRMS. The difference between these two instruments is that the high sensitivity instrument consists of an additional vacuum chamber and turbomolecular pump located between the drift tube and the quadrupole (de Gouw and Warneke, 2007). A number of rigorous validation experiments were used to ensure coherence between the two instruments; both instruments were collocated and shared a common inlet and operated using the same conditional parameters. The agreement between the two instruments during these experiments validates our ability to meaningfully compare the data sets generated by each and view the analysis of these measurements as one contiguous data set (e.g., White et al., 2008a).

\subsection{Deposition velocity calculations}

Following the method in Talbot et al. (2005) deposition velocities from the mean summer diurnal curves have been calculated. The calculation is simply: [(depletion rate pptv $\mathrm{h}^{-1}$ ) $\times$ (height of the layer below the nocturnal inversion $-\mathrm{m})] /[$ mean mixing ratio - pptv]. The units are then converted to $\mathrm{cm} \mathrm{s}^{-1}$. Here the height of the layer below the inversion is assumed to be $125 \mathrm{~m}$ (the upper limit of the 70$125 \mathrm{~m}$ range given in Talbot et al., 2005) and the interval used for the depletion in all cases was from 2200 to 04:00 EST. As shown by Talbot et al. (2005) nocturnal inversions are common at TF (occurring nearly $50 \%$ of the time in warm months) and the strong diurnal cycles observed here reflect the prevalence of those inversions. Another site they evaluated in this region showed weaker diurnal curves, attributed to the lower frequency of nocturnal inversions at that site.

Based on these results, we applied this calculation to the mean summer diurnal curves in order to compare the loss rate between the affected species reported here. However, the reader is strongly cautioned that these deposition velocities are not true dry deposition velocities and should not be interpreted as such. The nocturnal depletion observed for certain species (not all species are depleted at night) is due to a combination (Talbot et al., 2005) of dry deposition, wet removal (i.e., loss of soluble species to dew), chemical loss, and dilution by vertical mixing (Hurst et al., 2001). It is not possible within the framework of mean seasonal diurnal behavior to determine the relative contribution of each process for each species to the overall loss observed. Indeed by including all data in the calculation (both nights with and without a nocturnal inversion) the deposition velocities reported here are significantly lower than those reported by Talbot et al. (2005) (see Table 5 in that reference compared with Table 3 here). Again, here the intention is to describe mean behavior and to compare species in a consistent manner.

When there is a nocturnal inversion vertical mixing is anticipated to be limited, but when there is no inversion, dilution via vertical mixing may be the dominant nighttime 


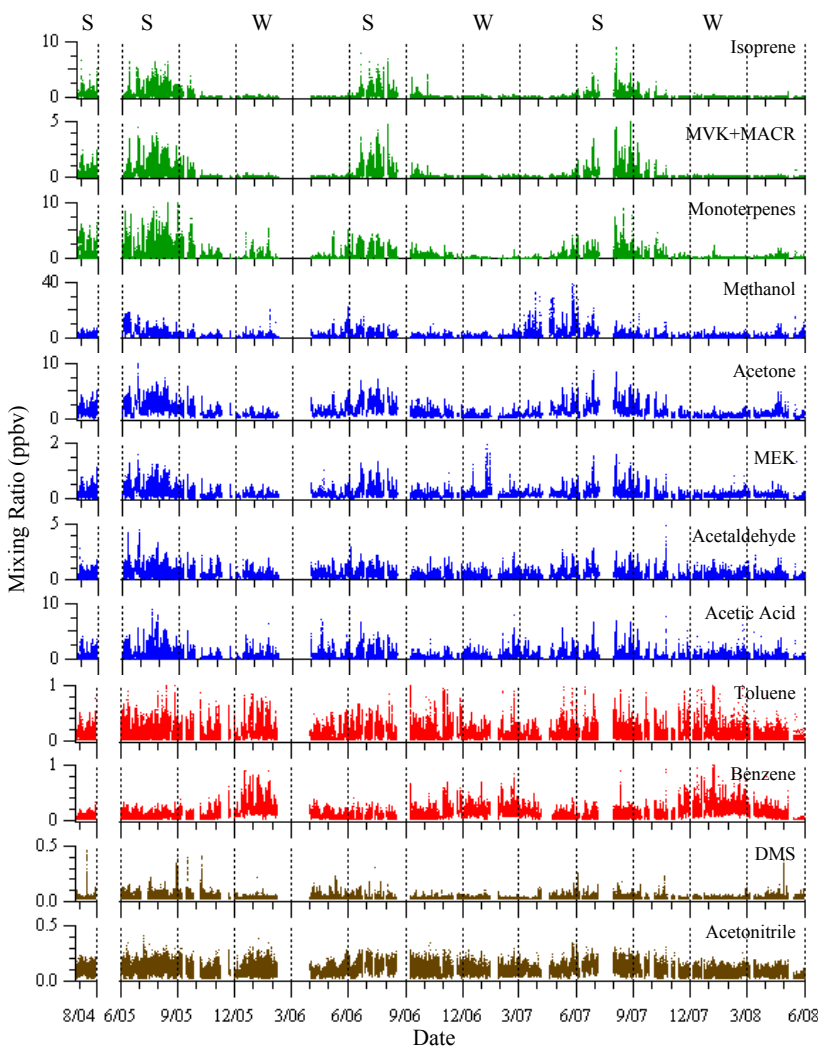

Fig. 2. Time series of measured compounds. Initial sampling conducted in summer 2004 (Jul-Aug). Continuous sampling followed from 1 June 2005 to 31 May 2008. Summers denoted with S, winters with W. Biogenic species shown in green, OVOCs in blue, aromatics in red, with DMS (marine) and acetonitrile (biomass burning) in brown. MVK+MACR are OVOCs, but they are principally oxidation products of isoprene, hence they are included with biogenics.

removal process. However, on average, for the species discussed here nocturnal depletion is followed by a rapid increase in mixing ratios after sunrise. This suggests that for these species, vertical mixing is not the dominant loss process on average in summer, since the mixing ratios in the remnant layer are higher than those near the surface. The mean influence of chemical loss is discussed in Sect. 4.1.3. We will use the term deposition velocity throughout the discussion, but one is advised to bear the preceding caveats in mind.

\section{Results - time series and statistics}

The time series plots (Fig. 2) and overall and seasonal statistics (Table 2) reveal the range of mixing ratios and seasonal variability observed at TF. Note, only values above the LOD (Table 1) are included in the statistical calculations shown in Table 2. Methanol (1.44 ppbv) and acetone (1.02 ppbv) ex- hibited the highest overall median mixing ratios observed at TF (Table 2), with 90th percentile mixing ratios of $4.56 \mathrm{ppbv}$ and 2.87 ppbv respectively.

\subsection{Seasonal characteristics}

Seasons here are defined as spring (March-May), summer (June-August), fall (September-November), and winter (December-February). As expected, the biogenic compounds showed the strongest seasonal variability (Fig. 2, Table 2) with median mixing ratios exhibiting a summer/winter ratio of $\sim 8$ for isoprene and $\mathrm{MVK}+\mathrm{MACR}$. Isoprene varied between $0.05-0.09 \mathrm{ppbv}$ in three seasons, compared to a median of $0.42 \mathrm{ppbv}$ in summer. MVK+MACR were 0.04-0.06 ppbv in three seasons compared to a median of $0.33 \mathrm{ppbv}$ in summer. Monoterpene median mixing ratios were 5 times higher in summer than winter.

Similar to seasonal behavior exhibited by the biogenic compounds, two OVOCs (MEK and acetaldehyde) had comparable median mixing ratios for three seasons $(0.10$ $0.11 \mathrm{ppbv}$ and $0.31-0.33 \mathrm{ppbv}$, respectively) with enhanced summer median mixing ratios $(0.22$ and $0.54 \mathrm{ppbv}$, respectively). In contrast, two other OVOCs (acetone and methanol) exhibited different seasonal behavior with low winter median mixing ratios $(0.57$ and $0.97 \mathrm{ppbv}$, respectively), high summer median mixing ratios (2.11 and 2.69 ppbv, respectively), and median mixing ratios in spring and fall in between these values. The last OVOC in this set (acetic acid) was the only compound reported here to have low fall median mixing ratios $(0.28 \mathrm{ppbv})$ with high summer median mixing ratios $(0.62 \mathrm{ppbv})$ and winter and spring in between $(0.39 \mathrm{ppbv}$ for both seasons).

The aromatics, unlike the biogenic compounds and OVOCs, generally did not exhibit strong seasonal variability (Fig. 2, Table 2). Toluene, $\mathrm{C}_{8}$ and $\mathrm{C}_{9}$ aromatics were all highest in summer with median mixing rations $0.14,0.12$, and 0.08 ppbv respectively, but only by factors of $\sim 1.1-1.3$ over their winter median values of $0.11,0.10$, and 0.06 respectively. In contrast, benzene did display strong seasonal variability with a median mixing ratio that was a factor of 2.5 higher in winter $(0.20 \mathrm{ppbv})$ than in summer $(0.08 \mathrm{ppbv})$. Aside from its winter increase, benzene levels remained fairly constant throughout the remainder of the year $(0.08$ 0.09 ppbv median mixing ratios).

Acetonitrile exhibited fairly uniform median mixing ratios over 3 seasons $(0.08-0.09 \mathrm{ppbv})$ with a summer value $(0.13 \mathrm{ppbv})$ a factor of 1.6 higher than that in winter. Finally, DMS showed a weaker seasonal variation with spring and summer median mixing ratios of $\sim 0.04 \mathrm{ppbv}$, a factor of 1.3 higher than in winter $(0.03 \mathrm{ppbv})$. However, it should be noted that unlike the other compounds here, DMS was generally below the $0.025 \mathrm{ppbv}$ limit of detection. Overall, it was above the detection limit only $22 \%$ of the time, with values above detection in winter $12 \%$ of the time and $29 \%$ in summer. 
Table 2. Medians (10th-90th percentiles).

\begin{tabular}{|c|c|c|c|c|c|c|c|c|}
\hline & $n$ & Isoprene (69) & MVK+MACR (71) & Monoterpenes (137) & Methanol (33) & Acetone (59) & MEK (73) & Acetaldehyde (45) \\
\hline Overall & 249036 & $0.10(0.03-0.82)$ & $0.07(0.03-0.78)$ & $0.24(0.07-1.46)$ & $1.44(0.53-4.56)$ & $1.02(0.42-2.87)$ & $0.13(0.05-0.37)$ & $0.37(0.16-0.96)$ \\
\hline Winter & 58586 & $0.05(0.03-0.15)$ & $0.04(0.02-0.08)$ & $0.10(0.06-0.36)$ & $0.97(0.43-2.39)$ & $0.57(0.35-1.07)$ & $0.11(0.06-0.23)$ & $0.33(0.16-0.74)$ \\
\hline Winter 2005 & 20348 & $0.06(0.03-0.17)$ & $0.04(0.02-0.08)$ & $0.11(0.06-0.54)$ & $1.03(0.41-2.40)$ & $0.60(0.37-1.16)$ & $0.11(0.06-0.23)$ & $0.33(0.17-0.72)$ \\
\hline Winter 2006 & 20706 & $0.05(0.02-0.12)$ & $0.04(0.02-0.08)$ & $0.08(0.05-0.21)$ & $0.91(0.42-2.31)$ & $0.53(0.33-1.14)$ & $0.12(0.06-0.28)$ & $0.30(0.15-0.78)$ \\
\hline Winter 2007 & 17532 & $0.05(0.03-0.15)$ & $0.04(0.02-0.09)$ & $0.09(0.06-0.27)$ & $0.98(0.46-2.51)$ & $0.56(0.36-0.93)$ & $0.11(0.06-0.19)$ & $0.34(0.18-0.73)$ \\
\hline Spring & $52466^{\mathrm{a}}$ & $0.05(0.02-0.14)$ & $0.04(0.02-0.12)$ & $0.12(0.06-0.61)$ & $1.31(0.50-5.04)$ & $0.93(0.41-2.10)$ & $0.11(0.05-0.25)$ & $0.31(0.14-0.81)$ \\
\hline Spring 2006 & 22516 & $0.05(0.02-0.14)$ & $0.04(0.02-0.11)$ & $0.12(0.06-0.70)$ & $1.31(0.46-4.39)$ & $1.05(0.44-2.24)$ & $0.11(0.04-0.27)$ & $0.36(0.16-0.86)$ \\
\hline Spring 2007 & 13430 & $0.06(0.02-0.17)$ & $0.05(0.02-0.17)$ & $0.13(0.06-0.78)$ & $2.23(0.78-8.31)$ & $1.02(0.53-2.50)$ & $0.14(0.07-0.31)$ & $0.34(0.16-0.92)$ \\
\hline Spring 2008 & 16381 & $0.04(0.02-0.10)$ & $0.04(0.02-0.08)$ & $0.12(0.06-0.41)$ & $0.91(0.45-2.70)$ & $0.71(0.31-1.45)$ & $0.10(0.04-0.20)$ & $0.24(0.10-0.60)$ \\
\hline Summer & 75513 & $0.42(0.09-1.53)$ & $0.33(0.06-1.47)$ & $0.50(0.13-2.51)$ & $2.69(1.14-6.54)$ & $2.11(0.98-4.08)$ & $0.22(0.08-0.60)$ & $0.54(0.21-1.27)$ \\
\hline Summer 2004 & 4113 & $0.37(0.08-1.11)$ & $0.33(0.06-1.04)$ & $0.46(0.12-2.71)$ & $1.97(0.82-3.86)$ & $1.43(0.71-2.91)$ & $0.17(0.05-0.46)$ & $0.39(0.12-0.92)$ \\
\hline Summer 2005 & 31077 & $0.49(0.11-1.69)$ & $0.36(0.07-1.52)$ & $0.71(0.17-3.31)$ & $2.81(1.18-7.29)$ & $2.19(0.95-4.07)$ & $0.25(0.09-0.62)$ & $0.64(0.23-1.38)$ \\
\hline Summer 2006 & 26638 & $0.41(0.08-1.44)$ & $0.32(0.05-1.45)$ & $0.35(0.12-1.57)$ & $2.76(1.24-6.22)$ & $2.13(1.06-4.24)$ & $0.20(0.07-0.63)$ & $0.49(0.20-1.18)$ \\
\hline Summer 2007 & 13685 & $0.34(0.08-1.34)$ & $0.27(0.05-1.54)$ & $0.43(0.11-2.01)$ & $2.61(1.00-6.26)$ & $2.01(1.01-4.14)$ & $0.21(0.08-0.58)$ & $0.47(0.20-1.15)$ \\
\hline Fall & 62471 & $0.09(0.03-0.41)$ & $0.06(0.03-0.37)$ & $0.23(0.07-0.98)$ & $1.13(0.51-2.70)$ & $1.00(0.45-2.20)$ & $0.10(0.04-0.29)$ & $0.33(0.15-0.86)$ \\
\hline Fall 2005 & 22896 & $0.08(0.03-0.57)$ & $0.06(0.03-0.47)$ & $0.30(0.10-1.46)$ & $1.11(0.50-2.91)$ & $1.04(0.43-2.32)$ & $0.10(0.04-0.32)$ & $0.39(0.17-0.99)$ \\
\hline Fall 2006 & 25789 & $0.08(0.03-0.31)$ & $0.05(0.03-0.20)$ & $0.18(0.06-0.79)$ & $1.06(0.49-2.40)$ & $0.97(0.49-2.00)$ & $0.10(0.05-0.26)$ & $0.30(0.14-0.73)$ \\
\hline \multirow[t]{2}{*}{ Fall 2007} & 13786 & $0.10(0.03-0.37)$ & $0.06(0.03-0.52)$ & $0.20(0.07-0.90)$ & $1.31(0.58-3.06)$ & $1.01(0.42-2.43)$ & $0.10(0.04-0.30)$ & $0.31(0.14-0.87)$ \\
\hline & $n$ & Acetic Acid (61) & Toluene (93) & $\mathrm{C}_{8}$ Aromatics (107) & $\mathrm{C}_{9}$ Aromatics (121) & Benzene (79) & Acetonitrile (42) & DMS (63) \\
\hline Overall & 249036 & $0.40(0.14-1.52)$ & $0.11(0.03-0.31)$ & $0.10(0.04-0.27)$ & $0.06(0.03-0.15)$ & $0.11(0.04-0.26)$ & $0.09(0.05-0.16)$ & $0.038(0.027-0.079)$ \\
\hline Winter & 58586 & $0.39(0.16-1.06)$ & $0.11(0.05-0.32)$ & $0.10(0.04-0.28)$ & $0.06(0.03-0.14)$ & $0.20(0.11-0.40)$ & $0.08(0.05-0.13)$ & $0.032(0.026-0.048)$ \\
\hline Winter 2005 & 20348 & $0.38(0.16-0.97)$ & $0.14(0.06-0.40)$ & $0.12(0.04-0.33)$ & $0.07(0.03-0.16)$ & $0.22(0.13-0.49)$ & $0.08(0.05-0.14)$ & $0.032(0.026-0.046)$ \\
\hline Winter 2006 & 20706 & $0.40(0.16-1.18)$ & $0.09(0.04-0.23)$ & $0.08(0.03-0.20)$ & $0.05(0.03-0.10)$ & $0.16(0.09-0.29)$ & $0.08(0.06-0.14)$ & $0.031(0.026-0.044)$ \\
\hline Winter 2007 & 17532 & $0.40(0.16-1.06)$ & $0.11(0.05-0.30)$ & $0.10(0.04-0.27)$ & $0.06(0.03-0.14)$ & $0.21(0.13-0.41)$ & $0.07(0.04-0.11)$ & $0.033(0.026-0.059)$ \\
\hline Spring & $52466^{\mathrm{a}}$ & $0.39(0.13-1.22)$ & $0.06(0.02-0.22)$ & $0.07(0.03-0.21)$ & $0.05(0.03-0.10)$ & $0.09(0.04-0.19)$ & $0.08(0.05-0.13)$ & $0.039(0.027-0.092)$ \\
\hline Spring 2006 & 22516 & $0.40(0.13-1.22)$ & $0.06(0.02-0.23)$ & $0.07(0.03-0.22)$ & $0.04(0.03-0.11)$ & $0.08(0.03-0.16)$ & $0.08(0.05-0.13)$ & $0.042(0.027-0.107)$ \\
\hline Spring 2007 & 13430 & $0.46(0.17-1.54)$ & $0.07(0.03-0.24)$ & $0.08(0.03-0.24)$ & $0.05(0.03-0.12)$ & $0.10(0.04-0.19)$ & $0.09(0.06-0.14)$ & $0.037(0.027-0.074)$ \\
\hline Spring 2008 & 16381 & $0.33(0.12-0.95)$ & $0.05(0.02-0.16)$ & $0.06(0.03-0.17)$ & $0.04(0.03-0.09)$ & $0.12(0.06-0.22)$ & $0.07(0.04-0.11)$ & $0.037(0.027-0.071)$ \\
\hline Summer & 75513 & $0.62(0.16-2.49)$ & $0.14(0.04-0.34)$ & $0.12(0.04-0.30)$ & $0.08(0.04-0.18)$ & $0.08(0.03-0.16)$ & $0.13(0.07-0.18)$ & $0.041(0.027-0.089)$ \\
\hline Summer 2004 & 4,113 & $0.62(0.15-2.05)$ & $0.10(0.04-0.26)$ & $0.10(0.04-0.27)$ & $0.08(0.03-0.18)$ & $0.06(0.03-0.13)$ & $0.11(0.06-0.16)$ & $0.039(0.027-0.105)$ \\
\hline Summer 2005 & 31077 & $0.70(0.17-2.74)$ & $0.15(0.05-0.34)$ & $0.14(0.05-0.33)$ & $0.10(0.04-0.20)$ & $0.08(0.04-0.14)$ & $0.13(0.07-0.18)$ & $0.045(0.028-0.094)$ \\
\hline Summer 2006 & 26638 & $0.54(0.14-2.23)$ & $0.13(0.04-0.34)$ & $0.10(0.04-0.25)$ & $0.07(0.04-0.14)$ & $0.08(0.03-0.16)$ & $0.13(0.07-0.19)$ & $0.036(0.026-0.072)$ \\
\hline Summer 2007 & 13685 & $0.62(0.17-2.29)$ & $0.13(0.04-0.35)$ & $0.12(0.04-0.29)$ & $0.08(0.04-0.17)$ & $0.09(0.04-0.18)$ & $0.13(0.07-0.20)$ & $0.041(0.027-0.092)$ \\
\hline Fall & 62471 & $0.28(0.12-1.06)$ & $0.11(0.03-0.31)$ & $0.11(0.04-0.27)$ & $0.07(0.03-0.15)$ & $0.09(0.04-0.23)$ & $0.09(0.05-0.15)$ & $0.037(0.027-0.067)$ \\
\hline Fall 2005 & 22896 & $0.31(0.12-1.27)$ & $0.10(0.03-0.28)$ & $0.10(0.04-0.28)$ & $0.07(0.04-0.17)$ & $0.07(0.03-0.18)$ & $0.09(0.04-0.15)$ & $0.039(0.027-0.071)$ \\
\hline Fall 2006 & 25789 & $0.26(0.11-0.80)$ & $0.11(0.03-0.33)$ & $0.11(0.04-0.27)$ & $0.06(0.03-0.14)$ & $0.10(0.04-0.25)$ & $0.10(0.05-0.15)$ & $0.033(0.026-0.056)$ \\
\hline Fall 2007 & 13786 & $0.30(0.12-1.35)$ & $0.11(0.03-0.31)$ & $0.11(0.04-0.28)$ & $0.06(0.03-0.14)$ & $0.11(0.05-0.27)$ & $0.09(0.05-0.15)$ & $0.035(0.027-0.067)$ \\
\hline
\end{tabular}

a includes 139 points from Spring 2005

In general the seasonal variability revealed in Fig. 2 and Table 2 reflect the expected influence of the summer growing season along with enhanced photochemistry at this time of year, the persistence of anthropogenic emissions throughout the year, and the prevalence of continental outflow at this site.

\subsection{Inter-annual comparisons}

In addition to these overall seasonal comparisons, Table 2 shows the yearly seasonal statistics. All seasons were measured for three years (1 June 2005 through 31 May 2008), plus there is an additional summer (2004). Note, Summer 2004 is significantly underrepresented with only $\sim 5$ weeks of data, 24 July-31 August. When comparing the summer median mixing ratios an interesting feature is apparent (Table 2): methanol, acetone, MEK, acetaldehyde, toluene, benzene, and acetonitrile median mixing ratios in summer 2004 are only $61 \%$ to $85 \%$ of medians reported in summer for the other 3 years. However, this is not the case for isoprene, monoterpenes, MVK+MACR, DMS, acetic acid, and the $\mathrm{C}_{8}$ and $\mathrm{C}_{9}$ aromatics. This result suggests that photochemistry (acetic acid), light and temperature (biogenics), and mobile emissions and photochemical removal $\left(\mathrm{C}_{8}\right.$ and $\mathrm{C}_{9}$ aromatics) were fairly consistent over these four summers. Hence these parameters are not likely candidates to explain the low median mixing ratios observed in summer 2004 for the other compounds.

Interannual comparisons for the other three seasons generally show modest variability from year to year. There are two notable exceptions (Fig. 2, Table 2): monoterpenes were higher in fall and winter 2005 than in 2006 or 2007, and methanol was much higher in spring 2007 than spring 2006 or 2008. Work is ongoing to investigate these unusual observations. 

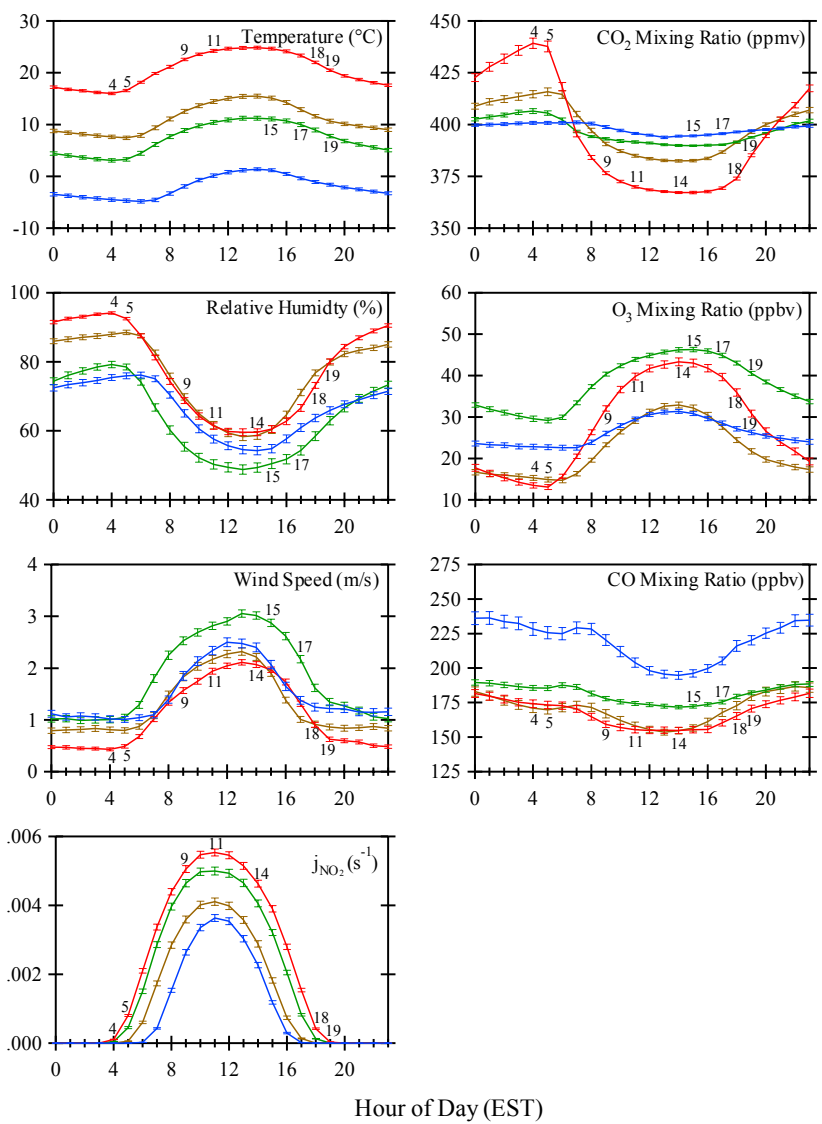

Fig. 3. Mean diurnal temperature, relative humidity, wind speed, $\mathrm{j}_{\mathrm{NO}_{2}}, \mathrm{CO}_{2}, \mathrm{O}_{3}$, and $\mathrm{CO}$ for summer (red), fall (gold), winter (blue), and spring (green). Time is in Eastern Standard Time (for all seasons, including summer) which is equivalent to Universal Time $5 \mathrm{~h}$.

\section{Discussion}

\subsection{Diurnal variability}

Mean diurnal curves are useful in illustrating typical behavior of various parameters, even though individual events, driven by transport and other specific meteorology may vary from the averages presented here. The physical parameters of temperature, relative humidity, wind speed, and $j_{\mathrm{NO}_{2}}$ all exhibited consistent diurnal patterns throughout the year, with the expected shifts in daylight $\left(\mathrm{j}_{\mathrm{NO}_{2}}\right)$ and temperature (Fig. 3). Relative humidity was highest in summer and fall, with pre-dawn maxima and mid-day minima. Wind speeds were highest in spring and winter, with mid-day maxima and nighttime minima.

Diel cycles of $\mathrm{CO}_{2}, \mathrm{O}_{3}$, and $\mathrm{CO}$ are also shown in Fig. 3 . $\mathrm{CO}_{2}$ and $\mathrm{O}_{3}$ exhibited their largest diurnal amplitudes in summer as expected from enhanced photosynthesis $\left(\mathrm{CO}_{2}\right)$ and photochemical processes $\left(\mathrm{O}_{3}\right)$ during this season. $\mathrm{CO}_{2}$ is observed to buildup under the nocturnal inversion and was drawn down during the day, primarily during summer and fall, and to a lesser degree in spring and winter. $\mathrm{O}_{3}$ removal was apparent during nighttime hours, most strongly in summer and spring, and built up during the day reaching its diurnal maxima in mid-afternoon. $\mathrm{CO}$ emissions are fairly uniform throughout the year, hence the higher values in winter reflect reduced $\mathrm{OH}$ photooxidation. In all seasons, $\mathrm{CO}$ was highest at night with a daytime minima.

\subsubsection{Marine tracer - DMS $\left(\left(\mathrm{CH}_{3}\right)_{2} \mathrm{~S}, \mathrm{~m} / \mathbf{z} 63\right)$}

Given the proximity of TF to the coast, DMS was monitored for evidence of oceanic air impacting this site. DMS is produced by phytoplankton (Bates et al., 1992) and has been reported to exhibit a diurnal cycle of daytime minima and nighttime maxima (Warneke and de Gouw, 2001; Hayward et al., 2002) attributed to its continuous production by phytoplankton with daytime removal primarily by $\mathrm{OH}$ (Cooper and Saltzman, 1991). As noted in Sect. 3.1, DMS measured by PTR-MS is usually below detection at TF. Little diurnal variation was observed (Fig. 4), and what there was may not be representative of the diurnal cycle at the coast. Values at TF were much lower (medians of 0.03-0.04 ppbv year round, Table 2) than those observed at various marine sites, $\sim 0.15$ 0.35 ppbv (Hayward et al., 2002, and references therein).

Marine sources of trace constituents have been shown to be important at TF (Zhou et al., 2005 and 2008; Chen et al., 2007; Varner et al., 2008). Previously reported measurements of marine tracers at TF (including DMS) have been performed with gas chromatography. Such measurements, primarily of various halocarbons, have been on the order of a few pptv or less (Zhou et al., 2005 and 2008; Varner et al., 2008). The apparent lack of DMS from the PTR-MS observations is principally due to the relatively high detection limit $(0.025 \mathrm{ppbv})$. DMS is observed to exceed the detection limit when meteorological conditions are such that on-shore flow brings marine-influenced air to the site from the Gulf of Maine, but is generally below detection for PTR-MS under other synoptic flow patterns, consistent with previously reported values at TF (Zhou et al., 2008).

\subsubsection{Biomass burning tracer - acetonitrile $\left(\mathrm{CH}_{3} \mathrm{CN}\right.$, $\mathbf{m} / \mathbf{z}$ 42)}

Acetonitrile is a tropospheric tracer of biomass burning (Lobert et al., 1990; Holzinger et al., 1999; Bange and Williams, 2000). Direct industrial emissions, fossil fuel combustion, and indirect production from agricultural fumigants are all minor sources contributing $<5 \%$ to its total emissions (Wisthaler et al., 2002, and references therein). There are no known sources from plants or soils (Wisthaler et al., 2002). Acetonitrile is removed from the atmosphere via reaction with $\mathrm{OH}$, wet deposition, and possibly loss to the ocean (via dissolving into the water and/or biological processes, de Gouw et al., 2003b). None of these loss processes are 
Table 3. Deposition velocity $\left(\mathrm{cm} \mathrm{s}^{-1}\right.$ ) calculated from observed rate of depletion in summer diurnal average (from 22:00 to 04:00 EST). Also, ratio of the mixing ratios at selected pairs of hours.

\begin{tabular}{lcccc}
\hline Compound $(s)$ & Protonated $\mathrm{m} / z$ & Deposition Velocity $\left(\mathrm{cm} \mathrm{s}^{-1}\right)$ & 05:00/04:00 EST Ratio & 06:00/05:00 EST Ratio \\
\hline Acetic Acid & 61 & 0.68 & 1.13 & 1.27 \\
MVK + Methacrolein & 71 & 0.67 & 1.06 & 1.53 \\
Isoprene & 69 & 0.35 & 1.22 & 1.57 \\
MEK & 73 & 0.34 & 1.07 & 1.19 \\
Acetaldehyde & 45 & 0.31 & 1.06 & 1.17 \\
Acetone & 59 & 0.20 & 1.01 & 1.11 \\
Methanol & 33 & 0.18 & 1.23 & 1.19 \\
Acetonitrile & 42 & 0.16 & 1.01 & 1.06 \\
\hline
\end{tabular}

particularly efficient, leading to a lifetime in the atmosphere of $\sim 0.5-1.5 \mathrm{y}$ depending upon whether an ocean sink is considered (former) or removal is restricted to wet deposition and reaction with $\mathrm{OH}$ (latter) (Hamm et al., 1984; Hamm and Warneck, 1990; Singh et al., 2003). Recent work (Sanhueza et al., 2004) has indicated that the ocean may act as a reservoir for acetonitrile, being a source in warm regions and a sink in cold regions.

Acetonitrile mixing ratios at $\mathrm{TF}$ in summer increased from $\sim 0.10$ ppbv before dawn (04:00 EST) to $\sim 0.14$ ppbv in midmorning (09:00 EST) with the mixing ratio constant throughout the rest of the day (Fig. 3). In early evening (19:00 EST) acetonitrile decreases, presumably as the nocturnal inversion sets up and reduces surface layer exchange from the remnant boundary layer aloft (Talbot et al., 2005). Dry deposition appears to reduce the mixing ratio under the inversion. A decrease was seen from 18:00 to 20:00, with a leveling off or slight increase observed from 20:00 to 21:00 prior to a steady decrease throughout the remainder of the night. The average diurnal cycle in summer suggests that acetonitrile does not have any local sources and that dry deposition is the primary sink. This interpretation of the diurnal cycle of acetonitrile is consistent with that of total gaseous mercury reported to have diel behavior controlled solely by mixing and dry deposition at this site (Mao et al., 2006).

Deposition velocities were calculated based on the observed depletion rate from 22:00 to 04:00 EST in summer. Assuming a boundary layer height of $125 \mathrm{~m}$ (Talbot et al., 2005) and a median nighttime mixing ratio of $0.11 \mathrm{ppbv}$, we obtain a dry deposition velocity of $0.16 \mathrm{~cm} \mathrm{~s}^{-1}$ (Table 3 ) which is consistent with the $0.14 \mathrm{~cm} \mathrm{~s}^{-1}$ value reported for a tropical savanna ecosystem (Sanhueza et al., 2004).

The mean diurnal mixing ratios observed throughout the year here range from $\sim 0.08-0.14 \mathrm{ppbv}$. These values are comparable to background values $(0.10-0.15 \mathrm{ppbv})$ reported elsewhere (Hamm and Warneck, 1990; Warneke and de Gouw, 2001; Wisthaler et al., 2002; Williams et al., 2004). The acetonitrile diurnal cycle in fall was similar to that in summer, but the difference in day/night mixing ratios was much smaller. The higher summertime values likely reflect increased occurrence of North American biomass burning and subsequent transport of plumes from this burning to the Northeastern US (Duncan et al., 2003; Duck et al., 2007; Park et al., 2007). In spring, the diurnal profile of acetonitrile was nearly flat with the difference between maxima $(\sim 0.09$ ppbv at 21:00 EST) and minima $(\sim 0.08$ ppbv at $14: 00$ EST) mean diurnal mixing ratios only $\sim 0.01 \mathrm{ppbv}$. Similarly, winter exhibited this same diurnal behavior with slightly enhanced amplitude, a difference of $\sim 0.02 \mathrm{ppbv}$ between maxima $(\sim 0.10 \mathrm{ppbv}$ at $21: 00 \mathrm{EST})$ and minima $(\sim 0.08 \mathrm{ppbv}$ at 11:00 EST). The mean seasonal diurnal behavior of acetonitrile suggests it may be used as a conservative tracer of boundary layer dynamics in interpreting the mean seasonal diurnal curves for the other species reported here.

\subsubsection{Biogenics - isoprene $\left(\mathrm{C}_{5} \mathrm{H}_{8}, \mathrm{~m} / \mathrm{z}\right.$ 69) and MVK + $\operatorname{MACR}\left(\mathrm{C}_{4} \mathrm{H}_{6} \mathrm{O}, \mathbf{m} / \mathbf{z} 71\right)$}

Isoprene is mainly emitted by chloroplasts as a function of light and temperature (Steeghs et al., 2004). Hence, isoprene emissions occur in the daytime and stop at night with summertime emissions exceeding those in winter. Isoprene readily reacts with $\mathrm{OH}$, its main daytime sink with an estimated lifetime of $0.07 \mathrm{~d}$ (Table 4). Two principal oxidation products of isoprene are MVK and MACR.

Although nighttime reaction of isoprene with $\mathrm{NO}_{3}$ (Table 4) can be an important removal mechanism affecting its diurnal cycle (Stroud et al., 2002), $\mathrm{NO}_{3}$ is likely suppressed at night both by prevalent monoterpenes (Warneke et al., 2004) and fresh NO emitted into the shallow nocturnal boundary layer by regional traffic (Stroud et al., 2002; Talbot et al., 2005; Ambrose et al., 2007). Hence, the nighttime oxidizing capacity of the nocturnal boundary layer is expected to be low at this site in summer. If the nighttime mixing ratio of isoprene is controlled by $\mathrm{NO}_{3}$ oxidation, then the ratio of MVK+MACR to isoprene should increase as isoprene is much more reactive with $\mathrm{NO}_{3}$ (Table 4). However, this ratio decreased from 0.86 to 0.62 over the nighttime interval of 22:00 to 04:00 EST in summer suggesting 

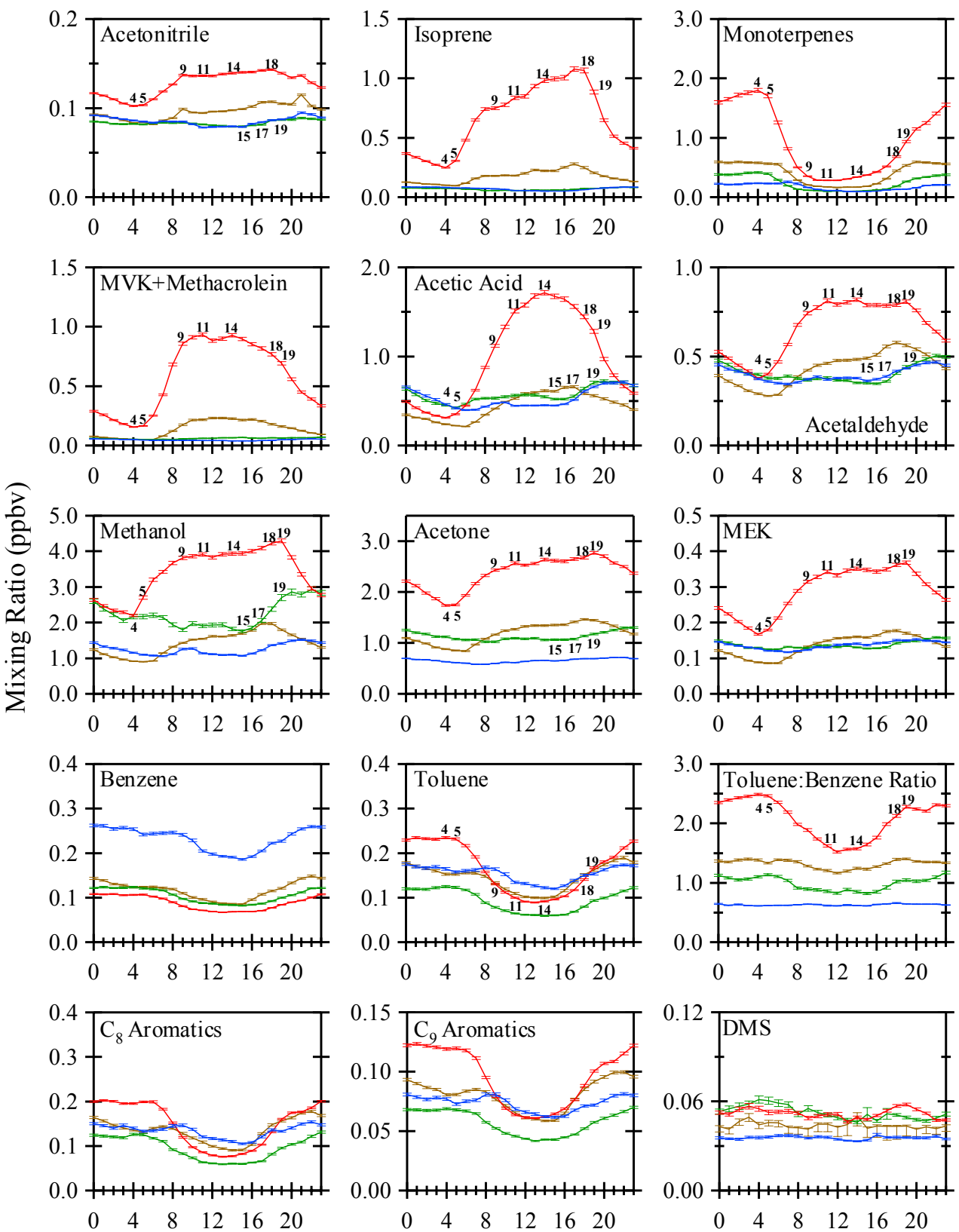

Hour of Day (EST)

Fig. 4. Mean diurnal mixing ratios for each reported compound with summer in red, fall in gold, winter in blue, and spring in green. Time is in Eastern Standard Time (including summer) which is equivalent to Universal Time $-5 \mathrm{~h}$.

dry deposition was the dominant nighttime removal mechanism. Calculating the deposition velocities (Table 3) as described for acetonitrile, we found values of 0.35 (isoprene) and $0.67 \mathrm{~cm} \mathrm{~s}^{-1}$ (MVK+MACR). These represent two of the three highest deposition velocities estimated for TF (acetic acid is $0.68 \mathrm{~cm} \mathrm{~s}^{-1}$ ).

As seen in the acetonitrile diurnal profile, there was a rapid mixing ratio increase after dawn as the inversion dissipated and the surface layer mixed with the remnant boundary layer air. The air mass mixing appeared to be complete by 08:00 EST rather than 09:00 EST as was seen with acetonitrile, but this difference likely reflects the balance between fresh emissions of isoprene and its removal by $\mathrm{OH}$.

Isoprene is observed to increase throughout the day in summer (Fig. 4) with inflections in the diurnal profile likely the result of shifts in the balance between emissions and loss by reaction with $\mathrm{OH}$. This is best seen by comparing the shape of the diurnal curve between isoprene and its 
Table 4. Rate constants at $298 \mathrm{~K}$ and estimated day and night lifetimes in summer.

\begin{tabular}{|c|c|c|c|c|c|}
\hline Compound & $\begin{array}{c}\mathrm{k}_{\mathrm{OH}} \times 10^{12} \\
\mathrm{~cm}^{3} \mathrm{molec}^{-1} \mathrm{~s}^{-1}\end{array}$ & $\begin{array}{c}\mathrm{k}_{\mathrm{NO}_{3}} \times 10^{12} \\
\mathrm{~cm}^{3} \mathrm{molec}^{-1} \mathrm{~s}^{-1}\end{array}$ & $\begin{array}{c}\mathrm{k}_{\mathrm{O}_{3}} \times 10^{18} \\
\mathrm{~cm}^{3} \mathrm{molec}^{-1} \mathrm{~s}^{-1}\end{array}$ & $\begin{array}{l}\text { Daytime Lifetime } \\
\text { in Summer (d) }\end{array}$ & $\begin{array}{l}\text { Nighttime Lifetime } \\
\text { in Summer (d) }\end{array}$ \\
\hline \multicolumn{6}{|l|}{ Biogenics } \\
\hline Isoprene & $100^{\mathrm{a}}$ & $0.7^{\mathrm{a}}$ & $12.7^{\mathrm{a}}$ & 0.07 & 0.06 \\
\hline Methyl vinyl ketone (MVK) & $20^{\mathrm{a}}$ & $<0.0006^{\mathrm{a}}$ & $5.2^{\mathrm{a}}$ & 0.32 & 4.21 \\
\hline Methacrolein (MACR) & $29^{\mathrm{a}}$ & $0.0034^{\mathrm{a}}$ & $1.2^{\mathrm{a}}$ & 0.26 & 7.98 \\
\hline \multicolumn{6}{|l|}{ Monoterpenes } \\
\hline$\alpha$-pinene & $53^{\mathrm{a}}$ & $6.2^{\mathrm{a}}$ & $90^{\mathrm{a}}$ & 0.06 & 0.01 \\
\hline$\beta$-pinene & $78.9^{\mathrm{b}}$ & $2.51^{\mathrm{b}}$ & $15^{\mathrm{b}}$ & 0.09 & 0.02 \\
\hline \multicolumn{6}{|l|}{ OVOCS } \\
\hline Acetone & $0.18^{\mathrm{a}}$ & - & - & 42.9 & - \\
\hline Acetic Acid & $0.74^{\mathrm{a}}$ & & & 10.4 & \\
\hline Methanol & $0.9^{\mathrm{a}}$ & - & - & 8.57 & - \\
\hline Methyl ethyl ketone (MEK) & $1.2^{\mathrm{a}}$ & & & 6.43 & \\
\hline Acetaldehyde & $15^{\mathrm{a}}$ & $0.0027^{\mathrm{a}}$ & - & 0.51 & 17.1 \\
\hline \multicolumn{6}{|l|}{ Aromatics } \\
\hline Benzene & $1.23^{\mathrm{b}}$ & - & - & 6.27 & - \\
\hline Toluene & $5.96^{\mathrm{b}}$ & - & - & 1.29 & - \\
\hline \multicolumn{6}{|l|}{$\mathrm{C}_{8}$ Aromatics } \\
\hline o-xylene & $13.7^{\mathrm{b}}$ & - & - & 0.56 & - \\
\hline m-xylene & $23.6^{\mathrm{b}}$ & - & - & 0.33 & - \\
\hline p-xylene & $14.3^{\mathrm{b}}$ & - & - & 0.54 & - \\
\hline \multicolumn{6}{|l|}{$\mathrm{C}_{9}$ Aromatics } \\
\hline 1,2,4-trimethylbenzene & $32.5^{\mathrm{b}}$ & - & - & 0.24 & - \\
\hline \multicolumn{6}{|l|}{ Tracers } \\
\hline Acetonitrile & $0.022^{\mathrm{a}}$ & & & 351 & \\
\hline DMS & $5.00^{\mathrm{b}}$ & $1.00^{\mathrm{b}}$ & $<1^{\mathrm{c}}$ & 1.34 & 0.05 \\
\hline
\end{tabular}

\footnotetext{
a Atkinson et al., 2006.

b From Tables B.1 and B.7 in Seinfeld, J. H. and Pandis, S. N. (1998)

c http://jpldataeval.jpl.nasa.gov/pdf/Atmos97_Anotated.pdf

Values used to calculate lifetimes: day: $[\mathrm{OH}]=1.5 \times 10^{6} \mathrm{~cm}^{-3} ;\left[\mathrm{NO}_{3}\right]=0 ;\left[\mathrm{O}_{3}\right]=1.125 \times 10^{12} \mathrm{~cm}^{-3}(45 \mathrm{ppbv})$. night: $[\mathrm{OH}]=0 ;\left[\mathrm{NO}_{3}\right]=2.5 \times 10^{8} \mathrm{~cm}^{-3}(10 \mathrm{pptv}) ;\left[\mathrm{O}_{3}\right]=5.0 \times 10^{11} \mathrm{~cm}^{-3}(20 \mathrm{ppbv})$.
}

products (following from reaction with $\mathrm{OH}$ ) MVK+MACR. $j_{\mathrm{NO}_{2}}$ peaks at midday (Fig. 3) resulting in peak mixing ratios of $\mathrm{OH}$. However, at the same time isoprene production should also peak. By 14:00 EST, as [OH] begins to decline, the diurnal curve of MVK+MACR begins its decline for the remainder of the day as less of these compounds are produced from isoprene and they are lost by $\mathrm{OH}$ attack. Isoprene was seen to continue increasing until early evening, as it continued to be emitted by trees in daylight, yet its loss was slowed as $[\mathrm{OH}]$ decreased. After 18:00 EST isoprene rapidly dropped as emissions ceased and removal processes dominated (White et al., 2008a).

As was the case for acetonitrile, the mean diurnal curve in autumn is similar to that of summer, but with lower mixing ratios. While in winter and spring, little variation was observed in the diurnal cycle, suggesting fresh emissions are minimal as was photochemical removal.

\subsubsection{OVOCs - acetic acid $\left(\mathrm{CH}_{3} \mathrm{COOH}, \mathrm{m} / \mathrm{z} 61\right)$}

Acetic acid is one of the most abundant organic acids in the atmosphere (Khare et al., 1999). The sources and sinks of acetic acid remain uncertain, hence the global budget is not well known (Rosado-Reyes and Francisco, 2006). Sources of acetic acid include vehicle emissions (Kawamura et al., 1985; Talbot et al., 1988), biomass burning (Talbot et al., 1988, 1995), emissions from ants (Graedel and Eisner, 1988), plants (Andreae, et al., 1988; Keene and Galloway, 1988; Talbot et al., 1990), soil (Sanhueza and Andreae, 1991: Enders et al., 1992; Sanhueza et al., 1996), oxidation of isoprene (Keene and Galloway, 1986; Talbot et al., 1988; Andreae et al., 1988; Jacob and Wofsy, 1988), ozonolysis of alkenes (including isoprene and monoterpenes, Calvert and Stockwell, 1983), peroxy acetyl radical reactions (Madronich and Calvert, 1990), and aqueous-phase oxidation of formaldehyde in cloud water (Chameides and 
Davis, 1983). Sinks of acetic acid are primarily dry and wet deposition (Rosado-Reyes and Francisco, 2006).

In summer and fall the diurnal cycle of acetic acid was similar to that of MVK+MACR (Fig. 4) and $\mathrm{O}_{3}$ (Fig. 3). Acetic acid exhibited the highest summertime deposition velocity reported here, $0.68 \mathrm{~cm} \mathrm{~s}^{-1}$ (Table 3 ). As with the previously discussed compounds, the mixing ratio of acetic acid rapidly increased after dawn and continued to increase until 14:00 EST. Like $\mathrm{O}_{3}$ and MVK+MACR, after this time, acetic acid mixing ratios declined. This was likely due to loss mechanisms dominating over production via photochemical processing. The close similarity of this curve to that of MVK+MACR suggests that this OVOC is predominantly produced in situ in the vicinity of this site, rather than directly emitted from biogenic (or other) sources.

Unlike isoprene, MVK+MACR, and acetonitrile, winter and spring mixing ratios of acetic acid exceeded those in summer and fall at night. For these colder seasons, there does appear to be nighttime loss over the 22:00 to 04:00 EST interval followed by a morning increase (delayed from that seen in summer, consistent with $j_{\mathrm{NO}_{2}}$, Fig. 3). The mixing ratios remained constant throughout the day until an increase was observed in the late afternoon and evening.

\subsubsection{Biogenics - monoterpenes $\left(\mathrm{C}_{10} \mathrm{H}_{16}, \mathrm{~m} / \mathbf{z} 137\right)$}

Monoterpenes are emitted by trees, both coniferous and deciduous (Kesselmeier and Staudt, 1999). These emissions are primarily a function of temperature (from stored pools such as resin ducts), although some species may also emit recently synthesized monoterpenes (as a function of light as well as temperature) (Lee et al., 2005 and references therein). Monoterpenes are highly reactive with $\mathrm{OH}$ (comparable to isoprene), $\mathrm{NO}_{3}$ and $\mathrm{O}_{3}$ (more so than isoprene for both of the latter oxidants, Table 4).

The contrast between the summertime diurnal cycle of isoprene versus that of monoterpenes was dramatic (Fig. 4), particularly given their comparable daytime reactivity with $\mathrm{OH}$ (Table 4). The difference between these profiles must result from a strong isoprene source, exceeding the capacity of $\mathrm{OH}$ at this site to remove it. However, the source of monoterpenes was insufficient to compete with daytime $\mathrm{OH}$ removal. As seen in other diurnal profiles, albeit in reverse, the monoterpenes mixing ratio begins to recover as $\mathrm{OH}$ declines and emissions continue, beginning slowly around 14:00 EST and increasing more rapidly after 16:00 EST. Daytime removal occurs in all four seasons (Fig. 4).

In summer, mixing ratios of monoterpenes were observed to increase throughout the night, but this was not observed during the other seasons. This difference is probably attributable to both enhanced nighttime emissions in this warm season and reduced $\mathrm{O}_{3}$ (Fig. 3) and $\mathrm{NO}_{3}$ sinks under the nocturnal inversion at this time of year (Talbot et al., 2005). This nighttime build-up of monoterpenes in summer also supports the contention of limited $\mathrm{NO}_{3}$ in the nighttime bound- ary layer as discussed above for isoprene and MVK+MACR (White et al., 2008a). Monoterpenes are highly reactive with both $\mathrm{NO}_{3}$ (lifetime $\sim 0.01-0.02 \mathrm{~d}$ using data given in Table 4) and $\mathrm{O}_{3}$ (lifetime $\sim 0.26-1.54 \mathrm{~d}$ ), with $\mathrm{NO}_{3}$ dominating the overall lifetime as shown in Table 4 . The fact that monoterpenes are observed to accumulate at night suggests there is limited $\mathrm{NO}_{3}$ (certainly $<10$ pptv (Brown et al., 2007) used in the Table 4 calculation).

\subsubsection{OVOCs}

The remaining OVOCs (acetaldehyde, methanol, acetone, and MEK) all appeared to have diurnal cycles similar to isoprene, suggesting these compounds may be emitted directly from biogenic sources, in addition to being produced photochemically from gas-phase precursors. All of these compounds exhibited profiles with peak mixing ratios in summer and fall just prior to sunset. The peak arrived an hour after that observed for isoprene suggesting either emissions continue later in the day or loss mechanisms were less efficient (all four of these compounds have lower deposition velocities than isoprene, Table 3), or both.

\subsubsection{OVOCs - acetaldehyde $\left(\mathrm{CH}_{3} \mathrm{CHO}, \mathrm{m} / \mathrm{z} 45\right)$}

Acetaldehyde exhibits a relatively constant temporal profile from 11:00 to 19:00 EST. This could be interpreted in a similar fashion as acetonitrile (i.e., that the diurnal curve reflects boundary layer dynamics coupled with dry deposition). However, its short lifetime with respect to $\mathrm{OH}$ (0.51 d, Table 4), comparable to that of MVK and MACR, argues against this interpretation. In addition, following its nighttime removal, its mixing ratio recovered from 04:00 to 09:00 EST (Fig. 4) as seen for acetonitrile. However, acetaldehyde mixing ratios further increased until 11:00 EST, a feature not seen in acetonitrile. This increase suggests either photochemical production or direct emission.

The mid-afternoon inflection observed between 11:00 and 12:00 (observed for all biogenic and OVOC compounds here) suggests removal exceeded production over this interval prior to increasing again until 14:00 EST. This loss was likely attributable to removal via $\mathrm{OH}$ at this time of day (see $j_{\mathrm{NO}_{2}}$ in Fig. 3). After 14:00 EST the curve decreased slightly, remained flat from 15:00 to 18:00 EST, with a slight increase at 19:00 EST then decreased throughout the night (with a calculated deposition velocity of $0.31 \mathrm{~cm} \mathrm{~s}^{-1}$, Table 3 ).

These results suggest that acetaldehyde sources and sinks are finely balanced throughout the day. The fact that the mixing ratio does not decline throughout the afternoon and evening like MVK+MACR, acetic acid and $\mathrm{O}_{3}$, suggests there are other sources than production from gas-phase precursors reacting with $\mathrm{OH}$. Acetaldehyde has been reported to have vegetation sources (Kesselmeier and Staudt, 1999). A laboratory study suggested acetaldehyde may be released throughout the day in forest canopies under shifting light 
conditions as part of normal leaf metabolism (Karl et al., 2002); perhaps such emissions affected the diurnal curve observed at TF.

Similar to acetic acid, winter and spring diurnal curves for acetaldehyde showed that the highest mixing ratios occurred around midnight, decreased to low early morning values with the mixing ratios remaining flat until 17:00 EST and increasing until midnight. This behavior may be a function of boundary layer height dynamics rather than either photochemical production or loss, since similar behavior is seen for acetonitrile.

\subsubsection{OVOCs - methanol $\left(\mathrm{CH}_{3} \mathrm{OH}, \mathrm{m} / \mathrm{z} \mathrm{33}\right)$}

Methanol is ubiquitous with mixing ratios in remote regions reported to be $\sim 1 \mathrm{ppbv}$, attributed to large vegetation sources and a relatively long atmospheric lifetime (here estimated to be $8.6 \mathrm{~d}$, Table 4) (de Gouw et al., 2003a). The source apportionment globally has been estimated to be $2 \%$ primary anthropogenic sources (from evaporation of solvents), $61 \%$ primary biogenic sources, $15 \%$ methane oxidation, 5$10 \%$ biomass burning, with the remaining $12-17 \%$ attributed to plant decay and/or ocean sources (Singh et al., 2000; Holzinger et al., 2005). In addition to the ocean and $\mathrm{OH}$ oxidation, wet and dry deposition to terrestrial ecosystems are also sinks for methanol (Galbally and Kirstine, 2002).

Biogenic emissions of methanol have been reported to occur in daylight and to be dependent on temperature (Baker et al., 2001; Schade and Goldstein, 2001; Harley et al., 2007) and stomatal control (MacDonald and Fall, 1993; Hüve et al., 2007; Harley et al., 2007). Such daytime emissions are consistent with isoprene, hence the similarity in their seasonal diurnal curves (Fig. 4). Methanol exhibited a much larger increase from 04:00 to 05:00 (0.50 ppbv) in summer than all other compounds except isoprene, increasing by a factor of 1.23 (Table 3). Isoprene increased by a factor of 1.22 , indicating that methanol has a very strong biogenic source. However, the shape of the curve throughout the remainder of the day, along with the relatively long lifetime of methanol, does not support that inference. If the source of methanol was as strong as isoprene, with a smaller sink, then it should steadily increase throughout the day. However, methanol's diurnal profile is quite similar to acetaldehyde, which appears to have relatively balanced sources and sinks. Looking at the rate of increase of all compounds over the next hour, 05:00 to $06: 00$, only methanol is observed to have a lower rate of increase than observed in the previous hour (1.19, Table 3).

Biogenic emissions of methanol have been reported to be controlled by the opening and closing of stomata (MacDonald and Fall, 1993; Hüve et al., 2007; Harley et al., 2007). Studies have shown that methanol can build up within the stomata during the night, releasing a large burst to the atmosphere when the stomata open, followed by emissions consistent with changes in stomatal conductance (Kirstine et al., 1998; Hüve et al., 2007) and temperature (Harley et al., 2007). The diurnal curve shown here is consistent with these laboratory studies reporting an early morning burst. Subsequently, methanol was observed here to increase until 11:00 EST, followed by a small downturn over the next hour, then a steady increase throughout the afternoon.

Intriguingly in springtime, a pronounced late afternoon rise was observed commencing at 15:00 EST. At this hour, slight increases in acetonitrile and acetone occurred (10\% and 15\%, respectively, from 15:00 to 20:00 EST), with larger increases in acetaldehyde and acetic acid (31\% and 38\%, respectively, over this interval), but no other OVOC increased as dramatically as methanol (62\% from 15:00 to 20:00 EST). Because methanol is not very reactive with $\mathrm{OH}$ (compared to most other compounds reported here), it is unlikely that this rise results from a reduced loss via reaction with $\mathrm{OH}$ (as is the case for monoterpenes and the aromatics); instead, this suggests an important fresh emission occurred.

Methanol has been reported to be associated with plant growth (a by-product of pectin hardening around cellulose) (Galbally and Kirstine, 2002; Keppler et al., 2004; Hüve et al., 2007). Methanol emissions from plant leaves are several-fold higher when the leaves are young and expanding than when they reach maturity (MacDonald and Fall, 1993; Nemecek-Marshal et al., 1995; Hüve et al., 2007; Harley et al., 2007). Indeed, growing tissues have been reported to contribute the most to plant-generated methanol in the atmosphere (Hüve et al., 2007). Hence, it is anticipated that methanol emissions will exhibit a seasonality consistent with plant growth (Galbally and Kirstine, 2002). We collected enclosure samples of methanol emissions in spring collected from loblolly pine and sweetgum trees at Duke Forest. These showed peak methanol emissions occurred in mid-afternoon. The sweetgum emissions remained high throughout the remainder of the day (unpublished data). Perhaps such plant growth emissions accumulate in the near surface boundary layer over the course of the day, resulting in the slowly increasing diurnal curve shown here (note, the ambient Duke Forest diurnal curve is very similar to this one). This is particularly provocative, since the rapid increase from 15:00 to 20:00 LT was second only to the rapid increase observed from 04:00 to 09:00 in summer (73\%) as the nocturnal inversion broke down.

\subsubsection{OVOCs - MEK $\left(\mathrm{C}_{2} \mathrm{H}_{5} \mathrm{COCH}_{3}, \mathrm{~m} / \mathrm{z} 73\right)$}

There are few reports of MEK (butanone) in the literature, hence, sources and sinks remain uncertain. MEK has been observed to have biogenic sources (Kirstine et al., 1998; de Gouw et al., 1999), and it is expected to be produced in the atmosphere from the oxidation of butane and higher hydrocarbons (de Gouw et al., 2003a). MEK was observed to constitute $45-50 \%$ of the VOC emissions from clover pastures in Australia (followed by methanol (15-33\%) and acetone (13-23\%), Kirstine et al., 1998). The biological mechanism that produces MEK, and the manner of its release to 
the atmosphere is unknown. However, the observations of Kirstine et al. (1998) indicate the emissions from undisturbed pasture were both a function of temperature and light, peaking at mid-day and ceasing at night. Kirstine et al. (1988) attribute this behavior to photosynthesis, stomatal control, or evaporation from leaf surface. By analogy with isoprene, they assert these emissions originate from the action of lightdependent enzymes within leaf tissue, and MEK is not stored in significant amounts within the plant.

At TF MEK was removed at night with a deposition velocity of $0.34 \mathrm{~cm} \mathrm{~s}^{-1}$ (Table 3 ). Its diurnal cycle follows the same pattern discussed thus far, with mixing following the breakdown of the nocturnal inversion, additional sources contributing to enhanced mixing ratios until 11:00 EST, a small downturn during peak $[\mathrm{OH}]$ at mid-day, with a peak observed at 19:00 EST. Again this late day peak likely reflects a biogenic primary source, rather than in situ production via $\mathrm{OH}$ reactions with precursors at this late hour.

The diurnal cycle of MEK in fall was similar to that in summer, but having lower mixing ratios. Daytime fall mixing ratios of MEK were only slightly higher than those in winter and spring. The lower nighttime values in fall likely reflect more efficient nighttime deposition under the nocturnal inversion, consistent with the lower nocturnal wind speeds observed at this time of year compared to winter and spring (Fig. 3).

\subsubsection{OVOCs - acetone $\left(\mathrm{CH}_{3} \mathrm{COCH}_{3}, \mathrm{~m} / \mathrm{z} 59\right)$}

Acetone is ubiquitous in the atmosphere (Warneke and de Gouw, 2001). The global budget of acetone has been apportioned (Jacob et al., 2002) to $1 \%$ primary anthropogenic emissions (from solvents and vehicle emissions), 35\% primary biogenic emissions, $22 \%$ secondary production from propane oxidation, 5\% biomass burning, with most of the rest emitted from oceans. Sinks are photolysis $(65 \%), \mathrm{OH}$ oxidation (25\%), and $10 \%$ due to wet and dry deposition (Singh et al., 1994, 1995). Deposition velocities of $\sim 0.17-$ $0.36 \mathrm{~cm} \mathrm{~s}^{-1}$ have been reported for the ocean (Mao et al., 2006; Warneke and de Gouw, 2001). Since acetone is both emitted from oceans and deposited to them, it has been suggested that oceans act as a reservoir for acetone, i.e., a sink for polluted air masses and a source for relatively clean air masses (Wisthaler et al., 2002; de Reus et al., 2003; Williams et al., 2004). In rural areas biogenic emissions of acetone have been reported to be substantial, e.g., $23 \%$ of total $\mathrm{C}$ emissions from a pasture of grass and clover in Australia (Kirstine et al., 1998).

Acetone exhibited a very similar diurnal profile to that of methanol and MEK, suggesting that in summer its diurnal cycle reflected a composite of daytime primary biogenic emissions, secondary formation, and nighttime removal. As with methanol (and unlike MEK), there was a clear distinction between spring and winter, with the former having mixing ratios almost a factor of 2 higher. In both seasons the diurnal curves were flat, resembling those of acetonitrile, suggesting that the mixing ratios during these seasons were controlled largely by transport and boundary layer height dynamics rather than in situ production and loss. The absence of a late afternoon spring peak suggests that any biogenic emissions of acetone emanate from a different source than methanol. The fall diurnal cycle was similar to the summer cycle, but at lower mixing ratios, as has been the case for acetonitrile and all biogenics and OVOCs.

\subsubsection{Aromatic compounds - benzene $\left(\mathrm{C}_{6} \mathrm{H}_{6}, \mathrm{~m} / \mathrm{z} 79\right)$, toluene $\left(\mathrm{C}_{7} \mathrm{H}_{8}, \mathrm{~m} / \mathbf{z} 93\right), \mathrm{C}_{8}(\mathrm{~m} / \mathbf{z} 107)$ and $\mathrm{C}_{9}$ $(\mathrm{m} / \mathrm{z} 121)$ aromatics}

Aromatic compounds are emitted to the atmosphere primarily via anthropogenic combustion given their prevalence in gasoline, with smaller additional contributions from industrial processes (Roberts et al., 1984). The principal loss mechanism for aromatics is reaction with $\mathrm{OH}$ (Table 4) resulting in atmospheric summer lifetimes typically on the order of hours ( $0.24 \mathrm{~d}, \mathrm{C}_{9}$ aromatics) to days ( $6.27 \mathrm{~d}$, benzene). In general, hydrocarbons have been observed to exhibit the same seasonal behavior as $\mathrm{CO}$, with mixing ratios at a minimum in summer and maximum in winter (Bottenheim and Shepherd, 1995; Goldstein et al., 1995). As with CO, anthropogenic emissions of hydrocarbons are largely seasonally invariant, with their seasonal variability attributed to their removal via OH (Bottenheim and Shepherd, 1995; Goldstein et al., 1995). Further, seasonal variations in rates for longrange transport of hydrocarbons play a relatively minor role in their seasonal cycles (Goldstein et al., 1995).

Here the diurnal cycle of benzene (Fig. 4) exhibits similar seasonality to $\mathrm{CO}$ (Fig. 3). Both have their highest mixing ratios in winter throughout the day and night. The remaining three seasons have comparable diurnal cycles and mixing ratios, although for $\mathrm{CO}$ spring is a bit higher than fall and summer, with more limited daytime removal.

Surprisingly, this is not the case for toluene and the $\mathrm{C}_{8}$ and $\mathrm{C}_{9}$ aromatics. Toluene has been reported to exhibit unusual seasonal behavior at TF (White et al., 2008b). Daily can measurements (usually obtained at mid-day) showed that unlike other anthropogenic hydrocarbons, toluene was elevated in summer and fall as well as winter $(85 \pm 5,88 \pm 5$ and $95 \pm 3$ pptv, respectively), with a spring minima ( $56 \pm 4$ pptv). White et al. (2008b) examined the summer enhancement of toluene in detail, attributing it to primarily a combination of enhanced fuel evaporation of reformulated gasoline with its higher toluene content (Lough et al., 2005) and to vegetative emissions, with a minor contribution from local industrial emissions. The vegetative emissions of toluene observed by White et al. (2008b) from a loblolly pine at Duke Forest were well correlated with monoterpenes.

Here, the diurnal cycles of toluene and the $\mathrm{C}_{8}$ and $\mathrm{C}_{9}$ aromatics are consistent with those findings based on daily data. All three of these exhibit their highest mixing ratios at night 
in summer, with a diurnal cycle consistent with monoterpenes (Fig. 4). Unlike monoterpenes, all three have elevated winter mixing ratios (due to reduced removal via $\mathrm{OH}$ ). The fall mixing ratios are comparable to or slightly higher than the winter values, with enhanced mid-day removal. Spring exhibits the lowest mixing ratios in all three cases.

\subsubsection{Aromatic compounds - toluene:benzene ratio}

For urban plumes traveling away from sources, the differing reaction rates of toluene and benzene with $\mathrm{OH}$ allows their ratio to be used as a photochemical clock. The ratio will change as a function of time as more of one compound is removed from the atmosphere than the other over a given interval (Roberts et al., 1984; McKenna et al., 1995). However, closer to sources where emissions should keep the ratio fairly constant, differing amounts of $\mathrm{OH}$ present in the atmosphere $\left(\sim 1.5 \times 10^{6}\right.$ molecules $\mathrm{cm}^{-3}$ in summer, $\sim 1.5 \times 10^{5}$ molecules $\mathrm{cm}^{-3}$ in winter for northern midlatitudes (Goldstein et al., 1995)), will lead to a distinct seasonal cycle in the ratio (lower in summer, higher in winter). In addition, for a ground station within a nocturnal inversion as is the case for TF, a strong diurnal cycle would be expected (higher nighttime ratio reflecting emissions, lower daytime ratio reflecting a lower value in the well-mixed boundary layer combined with $\mathrm{OH}$ preferentially removing toluene).

The summer toluene:benzene ratio exhibits the expected diurnal variability (Fig. 4) with mean nighttime values peaking at $\sim 2.5$ at $04: 00$ EST and midday values $\sim 1.5$. The observed nighttime peak is consistent with anthropogenic emissions of toluene:benzene reported to range from $\sim 2$ 3 (Salisbury et al., 2003). However, seasonally, the ratio does not change as expected. White et al. (2008b) found the toluene:benzene ratio from daily can measurements at TF reached their maximum in summer, $1.9 \pm 0.1$, significantly higher than the remainder of the year, $0.9 \pm 0.02$. Yet, the ethyne: $\mathrm{CO}$ ratio (also dependent on $\mathrm{OH}$ reactivity, with ethyne the more reactive) had the expected summer minimum due to higher $\mathrm{OH}$ mixing ratios. They attribute the enhanced summertime ratio to enhanced summertime sources of toluene as discussed above. However, the low wintertime ratio reported here also requires scrutiny.

Benzene and $\mathrm{CO}$ exhibit similar diurnal variation in all four seasons (Figs. 3 and 4, respectively). CO emissions to the atmosphere are dominated by mobile combustion sources (Parrish, 2006). With fairly uniform emissions year round, the observed seasonal variations in CO reflect the efficiency of its removal via OH photooxidation (Penkett et al., 1993; Jobson et al., 1994). At TF the mean winter diurnal cycle of $\mathrm{CO}$ had a 13\% drop in the mixing ratio between 06:00 (232 ppbv) and 14:00 h (202 ppbv, Fig. 3). This neglects the brief morning rush hour increase in $\mathrm{CO}$ up to $237 \mathrm{ppbv}$ at 07:00. A drop of $13 \%$ requires an $\mathrm{OH}$ concentration on the order of $10^{7}$ much too high for this region at this time of year. For $10^{5}$ molecules $\mathrm{cm}^{-3}$ of $\mathrm{OH},<1 \mathrm{ppb}$ of $\mathrm{CO}$ is removed
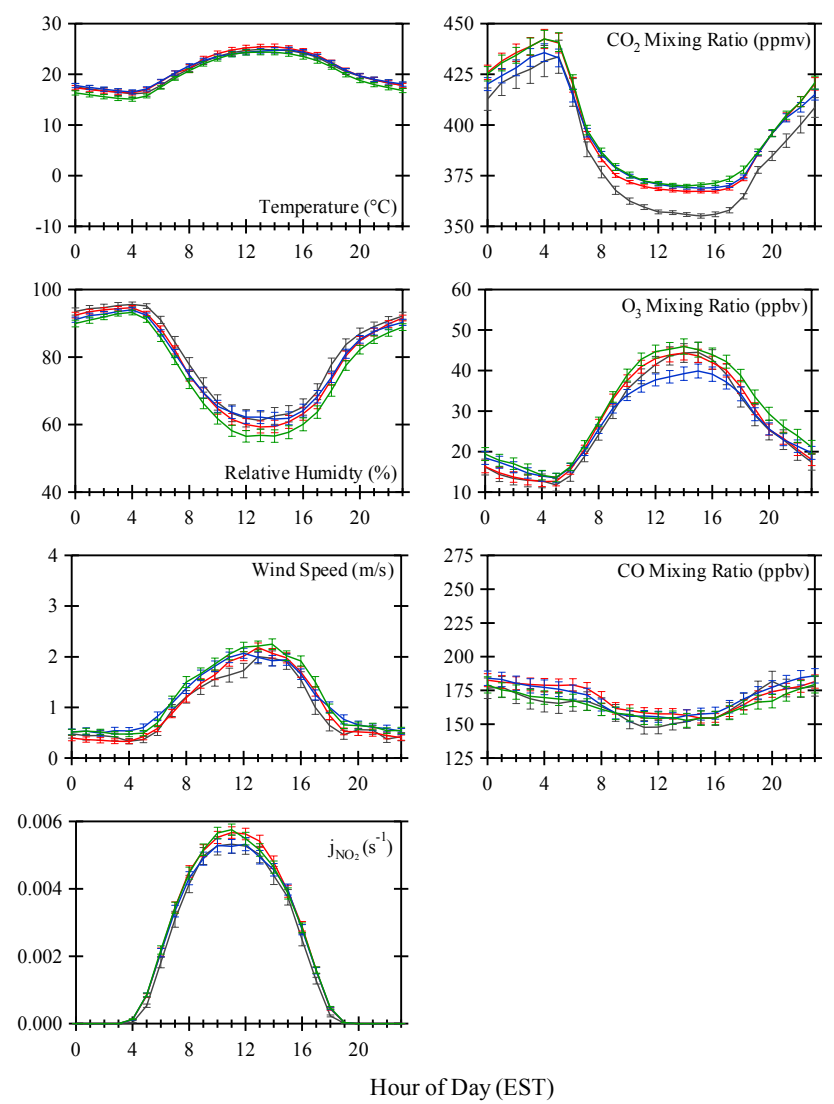

Fig. 5. Meteorological data along with $\mathrm{CO}_{2}, \mathrm{CO}$, and $\mathrm{O}_{3}$ for Summer (Jun-Aug) 2004 (gray), 2005 (red), 2006 (blue), and 2007 (green).

over this $8 \mathrm{~h}$ period. This suggests $\mathrm{CO}$ accumulates at night near the surface and mixes during the day with background air with lower mixing ratios of $\mathrm{CO}$.

Similarly, benzene and toluene also exhibit a decrease of $\sim 23 \%$ over the interval from 06:00 to 14:00. If CO is accumulating near the surface at night from mobile sources, then the nighttime toluene:benzene ratio should approach that of mobile sources as well. Salisbury et al. (2003) have reported such ratios should be in the range of 2-3. Recently, Schnitzhofer et al. (2008) have suggested that the toluene:benzene ratio in winter should be lower than that in summer due to reduced evaporation of toluene. However, Lough et al. (2005) conducted tunnel studies in Milwaukee, WI (latitude $43.11^{\circ} \mathrm{N}$, the same as TF) that show emissions of toluene are nearly constant throughout the year with mean emissions of $357 \pm 143 \mathrm{mg} \mathrm{L}^{-1}$ fuel in summer (largely due to evaporation) and $363 \pm 232 \mathrm{mg} \mathrm{L}^{-1}$ fuel in winter (largely due to incomplete combustion). Benzene emissions from mobile sources were observed to be $167 \pm 59 \mathrm{mg} \mathrm{L}^{-1}$ fuel in summer and $95 \pm 26 \mathrm{mg} \mathrm{L}^{-1}$ fuel in winter (Lough et al., 2005). Their results from two winter tunnel studies and a study of cold starts in a parking ramp suggest that even in 

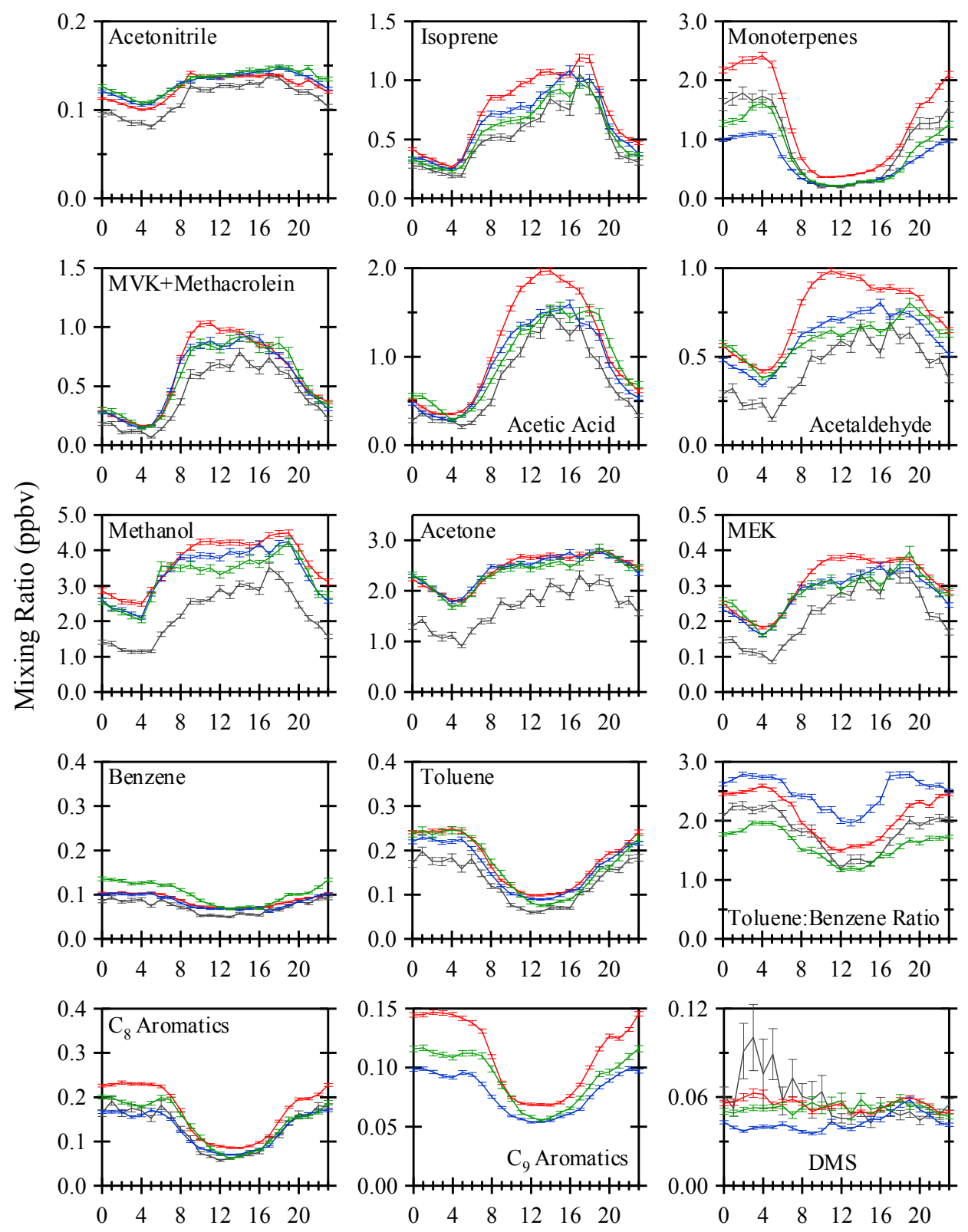

Hour of Day (EST)

Fig. 6. PTR-MS data for Summer (Jun-Aug) 2004 (gray), 2005 (red), 2006 (blue), and 2007 (green).

winter mobile emissions of toluene and benzene should lead to a ratio in the range from $\sim 2-5$ (Lough et al., 2005). So at TF, it would be expected that the toluene:benzene ratio would exhibit a diurnal cycle where the ratio increases at night to reflect recent mobile emissions, but it does not. The ratio is observed to remain constant throughout the day and night at $\sim 0.7$ (Fig. 4). This unchanging diurnal value is difficult to explain in the presence of accumulating fresh nighttime mobile emissions.

In addition to ratios measured from urban mobile emissions, toluene:benzene emission ratios have also been re- ported from various forms of biomass burning. While highly uncertain, the data suggest the ratio is consistently $<1$ with biofuel burning $\sim 0.58$ and extratropical forest fires $\sim 0.82$ (Andreae and Merlet, 2001). Charcoal burning and agricultural residues exhibit very low ratios, $<0.5$, but these numbers are based on very limited data (Andreae and Merlet, 2001). Perhaps then, the low value for this ratio observed here in winter reflects wood burning used for residential heating. 
In the United States emissions of $\mathrm{CO}$ from wood-burning stoves and furnaces accounts for only $2 \%$ of the total CO emissions annually (Parrish, 2006). However, the highest use of residential biofuel in the United States is in the northeast (Park et al., 2007). In the two counties closest to TF CO emissions from heating contribute $\sim 6 \%$ to the total winter CO emissions, $97 \%$ of which come from residential wood heating as estimated from the NEI99 (US EPA, 1999).

In New Hampshire, only $4.4 \%$ of homes use wood heat. The remainder use fuel oil (55.2\%), gas $(31.3 \%)$, electric $(7.8 \%)$ with other sources or no heat at all accounting for the rest (1.3\%) (http: //factfinder.census.gov/servlet/DTTable?_bm=y\&-geo_id= 04000US33\&-ds_name=ACS_2006_EST_G00_\&-mt_name= ACS_2006_EST_G2000_B25117). Such a small fraction of wood-burning for heating (not including aesthetic fireplaces) may be insufficient to reduce the overall toluene:benzene ratio to 0.7 . There is limited information on this ratio from furnaces in general, however one study showed wood-fired boilers exhibited toluene:benzene ratios of $\sim 0.2-0.4$ (Johansson et al., 2004). For comparison, they also assessed two oil-fired boilers in their study. One, a modern environmental brand (according to Nordic Ecolabeling of oil burners 2000-2004) had a ratio of 2 . The other, a multi-fuel boiler that could also burn wood logs and pellets (here run with oil) had a ratio of 0.5 . It should be noted that the emissions of toluene and benzene from the boilers in the Johansson et al. (2004) study ranged over four orders of magnitude with the largest emissions from old-style wood burners and lowest from the oil burners. There is insufficient information about toluene and benzene emissions from furnaces generally, or those in use in New Hampshire specifically, to estimate what such emissions might be. However, the diurnal cycle of $\mathrm{CO}$ and toluene:benzene when viewed together, suggest this question merits more attention.

It should be noted that the Schnitzhofer et al. (2008) study ruled out domestic wood combustion as a source of enhanced benzene (and hence lowered toluene:benzene ratio) on the basis of its ratio with acetonitrile. Here we see little diurnal variation of acetonitrile in winter, but there is a $17 \%$ difference between the nighttime maxima (99 pptv at 21:00 h) and daytime minima (82 pptv at 11:00 h). Nonetheless, it is not clear how much acetonitrile is emitted from domestic wood burning. Andreae and Merlet (2001) note there is very little data on emissions from wood and dung burning for domestic fuel, so they do not include any estimates for emissions from those sources. They note acetonitrile in particular as a compound for which much more data are needed. They also point out that $\mathrm{NO}, \mathrm{NO}_{2}, \mathrm{~N}_{2} \mathrm{O}$, and molecular $\mathrm{N}_{2}$ are emitted during flaming combustion, while nitriles (and $\mathrm{NH}_{3}$ and amines) are emitted under smoldering conditions. This raises the possibility that less acetonitrile is released in the controlled burning of a wood-fired boiler or stove, than is the case in an open fire. Unfortunately in the one study we could find on furnace emissions (Johansson et al., 2004) no
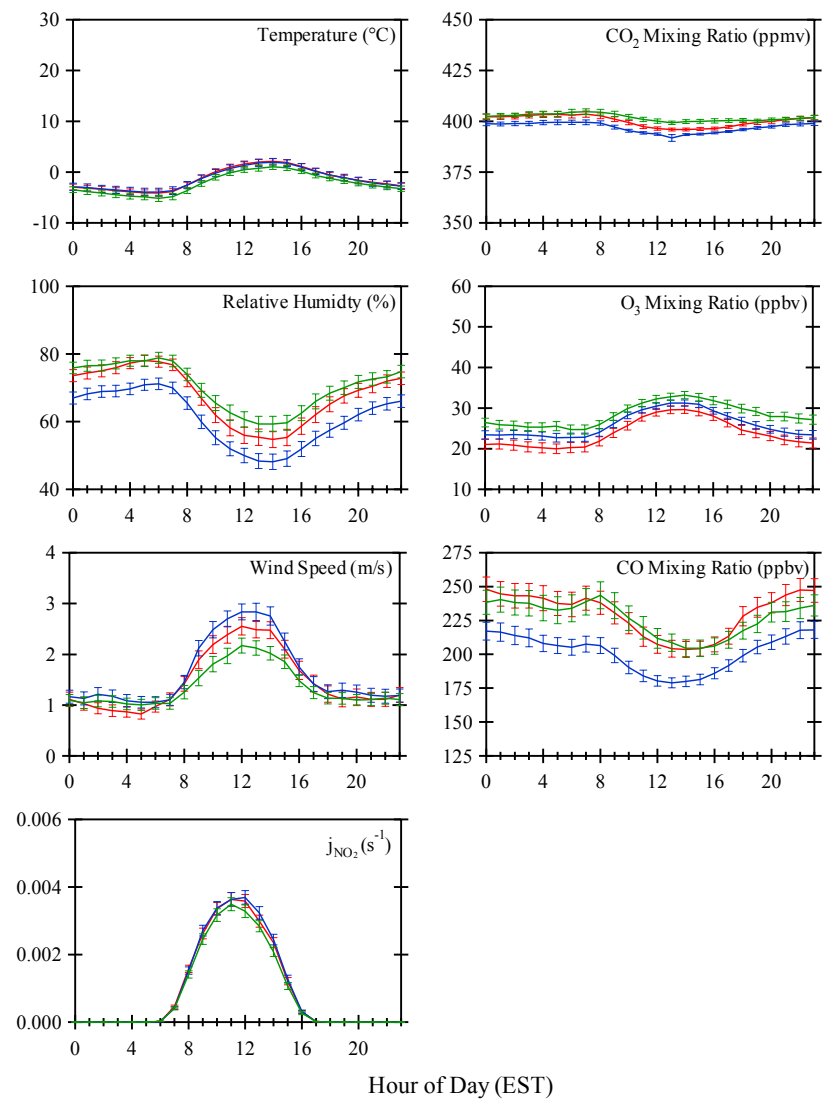

Fig. 7. Meteorological data along with $\mathrm{CO}_{2}, \mathrm{CO}$, and $\mathrm{O}_{3}$ for Winter (Dec-Feb) 2005/2006 (red), 2006/2007 (blue) and 2007/2008 (green).

data were reported for $\mathrm{N}$ containing compounds. It appears the Schnitzhofer et al. (2008) study relied on open biomass burning ratios to calculate their expected emissions of benzene from acetonitrile, but such ratios for domestic heating sources require further data to constrain potential emissions.

\subsection{Inter-annual diurnal comparisons}

In addition to the comparisons of the diurnal cycles between seasons, the length of time covered by this data set permits an inter-annual comparison of mean diurnal cycles for a given season. Here we briefly highlight some interesting features from comparisons in summer and winter diurnal profiles from different years.

\subsubsection{Summer}

Comparing the summer meteorological parameters along with $\mathrm{CO}_{2}, \mathrm{CO}$ and $\mathrm{O}_{3}$ (Fig. 5), minor variations in temperature, relative humidity, wind speed and sunlight (as indicated by $j_{\mathrm{NO}_{2}}$ ) were observed. Larger inter-annual variations among the diurnal curves of the compounds measured by PTR-MS are revealed in Fig. 6. As noted in the 

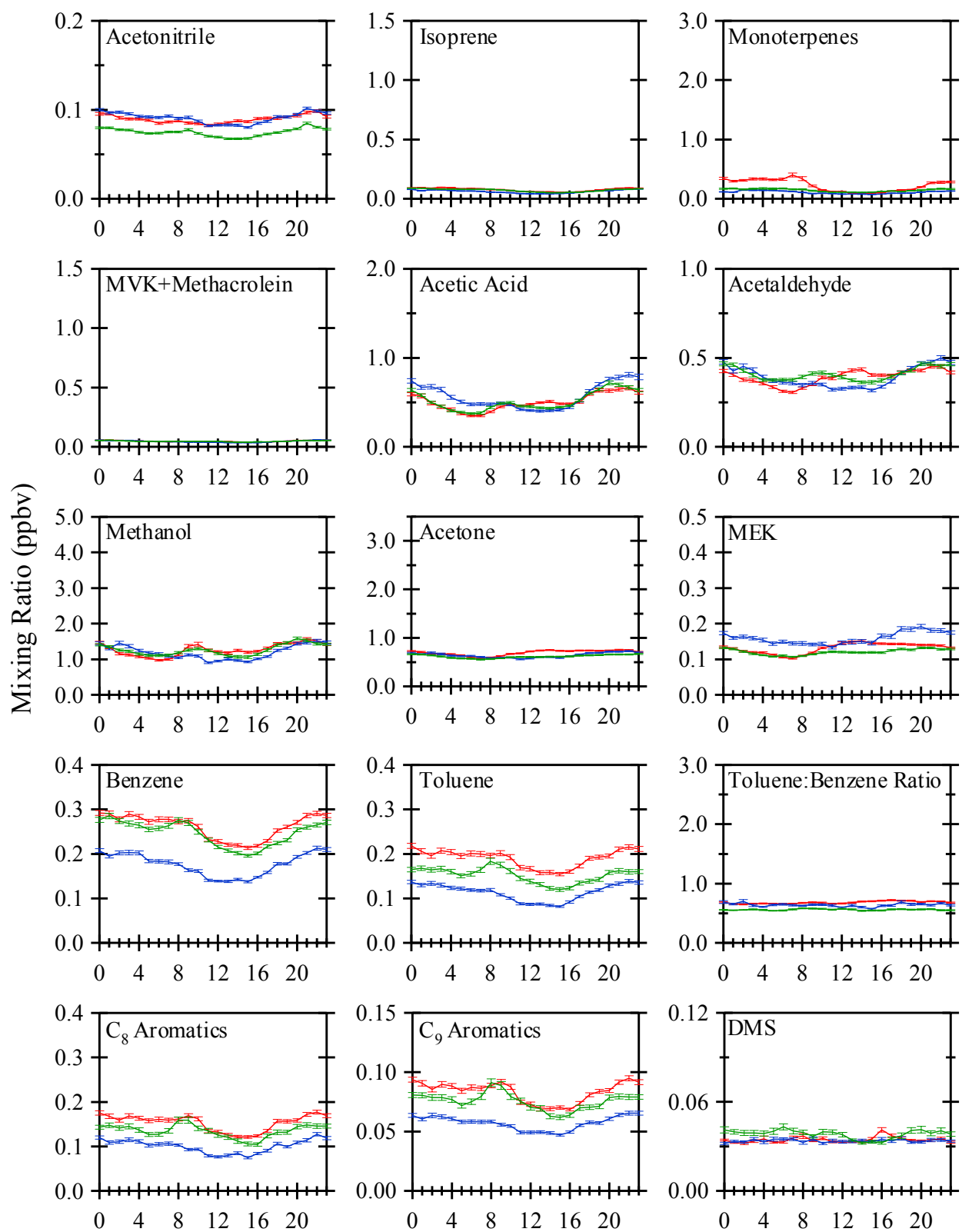

Hour of Day (EST)

Fig. 8. PTR-MS data for Winter (Dec-Feb) 2005/2006 (red), 2006/2007 (blue), and 2007/2008 (green).

discussion of the statistics, several compounds (particularly acetaldehyde, methanol, acetone, and MEK) showed substantially lower mixing ratios throughout the mean summer day of 2004. There was also quite of bit of variability in the toluene:benzene ratio from year to year, with the highest ratio in 2006 (mean diurnal average ranged from 2.0 at midafternoon up to 2.8 at night) and lowest in 2007 (mean diurnal average 1.2-2.0). This variability likely reflects not just emissions from mobile sources and their subsequent photochemical processing, but also fuel evaporation and biogenic emissions of toluene (White et al., 2008b).
Of particular note was the appearance in 2005 of a midday peak in MVK+MACR, acetaldehyde, MEK, and possibly methanol. This suggests that under different meteorological and possibly different transport regimes, the balance between in situ photochemical production and direct biogenic emissions of OVOCs may be shifted at this site, resulting in different shapes to the mean diurnal curve. Although the meteorological data only indicated relatively minor differences between the summers, the differences observed in mean temperature were found to be statistically significant at TF (White et al., 2008b) with $20041.4^{\circ} \mathrm{C}$ cooler than 
2005. 2005 had the highest temperature and $j_{\mathrm{NO}_{2}}$ mean diurnal curves (Fig. 5), presumably reflecting less cloud cover on average, which could result in higher photochemical production of secondary compounds.

\subsubsection{Winter}

The winter meteorological parameters show only minor variations in temperature and daylight between the winters of 2005/2006, 2006/2007 and 2007/2008 (Fig. 7). Similarly, most compounds generally showed minor inter-annual differences in winter, with the notable exception of $\mathrm{CO}$ (Fig. 7), monoterpenes, and the aromatics (Fig. 8). The aromatics, like $\mathrm{CO}$, are much higher throughout the day in winter 2005/2006 and 2007/2008 than winter 2006/2007. Interestingly, the toluene:benzene ratio is nearly identical in all three years. This suggests that the sources of the aromatics were consistent in all winters, but that the mixing ratios are lower in winter 2006/2007.

Monoterpenes were also observed to be higher in winter 2005/2006 than the other two winters; however the difference was only observed at night, with daytime values comparable for all winters. This indicates the presence of local winter sources of the monoterpenes. Preliminary results indicate the source of this mean diurnal monoterpene signature for 2005/2006 were nighttime monoterpene emission events that occurred under a nocturnal inversion when the wind speed drops below $0.5 \mathrm{~m} \mathrm{~s}^{-1}$. However, monoterpene events did not always occur when the wind speed was low. We are continuing to investigate factors that control the occurrence of these events.

\section{Summary}

We have presented observations from a long-term high timeresolution data set obtained at a rural site in southeastern $\mathrm{NH}$ that is subject to urban and marine influences. This extensive (and on-going) data set has been used to establish the mean characteristics of the compounds measured. Comparing multiple compounds sheds light on not just similarities, but differences that may be useful in guiding work to better understand specific sources and production mechanisms of these compounds. Further, these mean characteristics can be used to guide analysis of unusual events of interest that occur at this site. It is hoped that over time continued measurements will be useful in further understanding local controls (such as meteorological conditions, specific vegetation, evolving anthropogenic emissions) on the observed mixing ratios, versus the influence of transport on the air composition and its evolution in this region.

Acknowledgements. Financial support for this work was provided through the Office of Oceanic and Atmospheric Research at the National Oceanic and Atmospheric Administration under grants NA04OAR4600154 and NA05OAR4601080. We thank Y. Zhou,
R. Russo, J. Ambrose, M. White, H. Mao and others who have contributed to the measurements and management of the extensive AIRMAP database.

Edited by: J. W. Bottenheim

\section{References}

Ambrose, J. L., Mao, H., Mayne, H. R., Stutz, J., Talbot, R., and Sive, B. C.: Nighttime nitrate radical chemistry at Appledore Island, Maine during the 2004 International Consortium for Atmospheric Research on Transport and Transformation, J. Geophys. Res., 112, D21302, doi:10.1029/2007JD008756, 2007.

Andreae, M. O. and Merlet, P.: Emission of trace gases and aerosols from biomass burning, Global Biogeochem. Cy., 15, 955-966, 2001.

Andreae, M. O., Talbot, R. W., Andreae, T. W., and Harriss, R. C.: Formic and acetic acids over the central Amazon region, Brazil, 1, Dry season, J. Geophys. Res., 93, 1616-1623, 1988.

Apel, E. C., Calvert, J. G., Greenberg, J. P., Riemer, D., Zika, R., Kleindienst, T. E., Lonneman, W. A., Fung, K., and Fujita, E.: Generation and validation of oxygenated volatile organic carbon standards for the 1995 Southern Oxidants Study Nashville Intensive, J. Geophys. Res., 103, 22281- 22944, 1998.

Atkinson, R., Cox, R. A., Crowley, J. N., Hampson Jr. R. F., Hynes, R. G., Jenkin, M. E. Kerr, J. A., Rossi, M. J., and Troe, J.: Summary of evaluated kinetic and photochemical data for atmospheric chemistry, Section II - organic reactions, IUPAC Subcommittee on Gas Kinetic Data Evaluation for Atmospheric Chemistry, Web version, available at: http://www.iupac-kinetic. ch.cam.ac.uk/, February 2006,

Baker, B., Guenther, A., Greenberg, J., and Fall, R.: Canopy level fluxes of 2-methyl-3-buten-2-ol, acetone, and methanol by a portable relaxed eddy accumulation system, Environ. Sci. Technol., 35, 1701-1708, 2001.

Bange, H. W. and Williams, J.: New directions: Acetonitrile in atmospheric and biogeochemical cycles, Atmos. Environ., 34, 4959-4960, 2000.

Bates, T. S., Lamb, B. K., Guenther, A., Dignon, J., and Stoiber, R. E.: Sulfur emissions to the atmosphere from natural sources. J. Atmos. Chem., 14, 315-337, 1992.

Bottenheim, J. W. and Shepherd, M. F.: $\mathrm{C}_{2}-\mathrm{C}_{6}$ hydrocarbon measurements at four rural locations across Canada, Atmos. Environ., 29, 647-664, 1995.

Brown, S. S., Dube, W. P., Osthoff, H. D., Stutz, J., Ryerson, T. B., Wollny, A. G., Brock, C. A., Warneke, C., de Gouw, J. A., Atlas, E., Neuman, J. A., Holloway, J. S., Lerner, B. M., Williams, E. J., Kuster, W. C., Goldan, P. D., Angevine, W. M., Trainer, M., Fehsenfeld, F. C., and Ravishankara, A. R.: Vertical profiles in $\mathrm{NO}_{3}$ and $\mathrm{N}_{2} \mathrm{O}_{5}$ measured from an aircraft: Results from the NOAA P-3 and surface platforms during the New England Air Quality Study 2004, J. Geophys. Res., 112, D22304, doi:10.1029/2007JD008883, 2007.

Calvert, J. G. and Stockwell, W. R.: Acid generation in the troposphere by gas phase chemistry, Environ. Sci. Technol., 17, 428A443A, 1983.

Chameides, W. L. and Davis, D. D.: Aqueous phase source of formic acid in clouds, Nature, 304, 427-429, 1983. 
Chen, M., Talbot, R. W., Mao, H., Sive, B., Chen, J., and Griffin, R.: Air mass classification in coastal New England and its relationship to meteorological conditions, J. Geophys. Res., 112, D10S05, doi:10.1029/2006JD007687, 2007.

Cooper, D. J. and Saltzman, E. S.: Measurements of atmospheric dimethyl sulfide and carbon-disulfide in the western Atlantic boundary-layer, J. Atmos. Chem., 12, 153-168, 1991.

de Gouw, J. A., Howard, C. J., Custer, T. G., and Fall, R.: Emissions of volatile organic compounds from cut grass and clover are enhanced during the drying process, Geophys. Res. Lett., 26, 811-814, 1999.

de Gouw, J., Warneke, C., Karl, T., Eerdekens, G., van der Veen, C., and Fall, R.: Sensitivity and specificity of atmospheric trace gas detection by proton-transfer-reaction mass spectrometry, Int. J. Mass Spectrom., 223-224, 365-382, 2003a.

de Gouw, J. A., Warneke, C., Parrish, D. D., Holloway, J. S., Trainer, M., and Fehsenfeld, F. C.: Emission sources and ocean uptake of acetonitrile $\left(\mathrm{CH}_{3} \mathrm{CN}\right)$ in the atmosphere, J. Geophys. Res., 108, 4329, doi:10.1029/2002JD002897, 2003 b.

de Gouw, J. and Warneke, C.: Measurements of volatile organic compounds in the earths atmosphere using proton-transferreaction mass spectrometry, Mass Spectrom. Rev. 26, 223-257, 2007.

de Reus, M., Fischer, H., Arnold, F., de Gouw, J., Holzinger, R., Warneke, C., and Williams, J.: On the relationship between acetone and carbon monoxide in different air masses, Atmos. Chem. Phys., 3, 1709-1723, 2003, http://www.atmos-chem-phys.net/3/1709/2003/.

Duck, T. J., Firanski, B. J., Millet, D. B., Goldstein, A. H., Allan, J., Holzinger, R., Worsnop, D. R., White, A. B., Stohl, A., Dickinson, C. S., and van Donkelaar, A.: Transport of forest fire emissions from Alaska and the Yukon Territory to Nova Scotia during summer 2004, J. Geophys. Res., 112, D10S44, doi:10.1029/2006JD007716, 2007.

Duncan, B. N., Martin, R. V., Staudt, A. C., Yevich, R., and Logan, J. A.: Interannual and seasonal variability of biomass burning emissions constrained by satellite observations, J. Geophys. Res., 108, 4100, doi:10.1029/2002JD002378, 2003.

Enders, G., Dlugi, R., Steincrecher, R., Clement, B., Daiber, R., Eijik, J. V., Gab, S., Haziza, M., Helas, G., Hermann, U., Kessel, M., Kesselmeier, J., Kotzias, D., Kourtidis, K., Kurth, H. H., McMillen, R. T., Roider, G., Schurmann, W., Teichmann, U., and Torres, L.: Biosphere atmosphere interactions - integrated research in a European coniferous forest ecosystem, Atmos. Environ., 26, 171-189, 1992.

Filella, I. and Penuelas, J.: Daily, weekly, and seasonal time courses of VOC concentrations in a semi-urban area near Barcelona, Atmos. Environ., 40, 7752-7769, 2006.

Galbally, I. E. and Kirstine, W.: The production of methanol by flowering plants and the global cycle of methanol, J. Atmos., Chem., 43, 195-229, 2002.

Gautrois, M., Brauers, T., Koppmann, R., Rohrer, F., Stein, O., and Rudolph, J.: Seasonal variability and trends of volatile organic compounds in the lower polar troposphere, J. Geophys. Res., 108, 4393, doi:10.1029/2002JD002765, 2003.

Goldstein, A. H., Wofsy, S. C., and Spivakovsky, C. M.: Seasonal variations of nonmethane hydrocarbons in rural New England: Constraints on $\mathrm{OH}$ concentrations in northern midlatitudes, J. Geophys. Res., 100, 21023-21033, 1995.
Graedel, T. E. and Eisner, T.: Atmospheric formic acid from formicine ants: A preliniary assessment, Tellus, Ser. B, 40, 335339, 1988.

Hamm, S. and Warneck, P.: The interhemispheric distribution and the budget of acetonitrile in the troposphere, J. Geophys. Res., 95, 20593-20606, 1990.

Hamm, S., Hahn, J., Helas, G., and Warneck, P.: Acetonitrile in the troposphere-Residence time due to rainout and uptake by the ocean, Geophys. Res. Lett., 11, 1207-1210, 1984.

Harley, P., Greenberg, J., Niinemets, U., and Guenther, A.: Environmental controls over methanol emission from leaves, Biogeosciences, 4, 1083-1099, 2007, http://www.biogeosciences.net/4/1083/2007/.

Hayward, S., Hewitt, C. N., Sartin, J. H., and Owen, S. M.: Performance characteristics and applications of a proton transfer reaction-mass spectrometer for measuring volatile organic compounds in ambient air, Environ. Sci. Technol., 36, 1554-1560, 2002.

Holzinger, R., Warneke, C., Hansel, A., Jordan, A., Lindinger, A., Scharffe, D. H., Schade, G., and Crutzen, P. J.: Biomass burning as a source of formaldehyde, acetaldehyde, methanol, acetone, acetonitrile, and hydrogen cyanide, Geophys. Res. Lett., 26, 1161-1164, 1999.

Holzinger, R., Williams, J., Salisbury, G., Klupfel, T., de Reus, M., Traub, M., Crutzen, P. J., and Lelieveld, J.: Oxygenated compounds in aged biomass burning plumes over the Eastern Mediterranean: evidence for strong secondary production of methanol and acetone, Atmos. Chem. Phys., 5, 39-46, 2005, http://www.atmos-chem-phys.net/5/39/2005/.

Hurst, J. M., Barket, D. J. Jr., Herrera-Gomez, O., Couch, T. L., Shepson, P. B., Faloona, I., Tan, D., Brune, W., Westberg, H., Lamb, B., Biesenthal, T., Young, V., Goldstein, A., Munger, J. W., Thornberry, T., and Carroll, M. A.: Investigation of the nighttime decay of isoprene, J. Geophys. Res., 106, 24335-24346, 2001.

Hüve, K., Christ, M. M., Kleist, E., Uerlings, R., Niinemets, U., Walter, A., and Wildt, J.: Simultaneous growth and emission measurements demonstrate an interactive control of methanol release by leaf expansion and stomata, J. Exp. Bot., 58, 1783-1793, 2007.

Jacob, D. J. and Wofsy, S. C.: Photochemistry of biogenic emissions over the Amazon forest, J. Geophys. Res., 93, 1477-1486, 1988.

Jacob, D., Field, B., Yin, E., Bey, I., Li, Q., Logan, J., Yantosca, R., and Singh, H.: Atmospheric budget of acetone, J. Geophys. Res., 107, 4100, doi:10.1029/2001JD000694, 2002.

Jobson, B. T., Wu, Z., Niki, H., and Barrie, L. A.: Seasonal trends of isoprene, $\mathrm{C}_{2}-\mathrm{C}_{5}$ alkanes, and acetylene at a remote boreal site in Canada, J. Geophys. Res., 99, 1589-1599, 1994.

Johansson, L. S., Leckner, B., Gustavsson, L., Cooper, D., Tullin, C., and Potter, A.: Emission characteristics of modern and oldtype residential boilers fired with wood logs and wood pellets, Atmos. Environ., 38, 4183-4195, 2004.

Karl, T., Curtis, A. J., Rosenstiel, T. N., Monson, R. K., and Fall, R.: Transient releases of acetaldehyde from tree leaves - products of a pyruvate overflow mechanism?, Plant Cell Environ., 25, 11211131, 2002.

Karl, T., Hansel, A., Mark, T., Lindinger, W., and Hoffman, D.: Trace gas monitoring at the Mauna Loa Baseline observatory using proton-transfer reaction mass spectrometry, Int. J. Mass 
Spectrom., 223, 527-538, 2003.

Kawamura, K., Ng, L. L., and Kaplan, I. R.: Determination of organic acids $\left(\mathrm{C}_{1}-\mathrm{C}_{10}\right)$ in the atmosphere, motor exhaust and engine oils, Environ. Sci. Technol., 19, 1082-1086, 1985.

Keene, W. C. and Galloway, J. N.: Considerations regarding sources for formic and acetic acids in the troposphere, J. Geophys. Res., 91, 14466-14474, 1986.

Keene, W. C. and Galloway, J. N.: The biogeochemical cycling of formic and acetic acids through the troposphere: An overview of current understanding, Tellus, Ser. B, 40, 322-334, 1988.

Keppler, F., Kalin, R. M., Harper, D. B., McRoberts, W. C., and Hamilton, J. T. G.: Carbon isotope anomaly in the major plant $\mathrm{C}_{1}$ pool and its global biogeochemical implications, Biogeosciences, 1, 123-131, 2004,

http://www.biogeosciences.net/1/123/2004/.

Kesselmeier, J. and Staudt, M.: Biogenic volatile organic compounds (VOC): An overview on emission, physiology, and ecology, J. Atmos. Chem., 33, 23-88, 1999.

Khare, P., Kumar, N., Kumari, K. M., and Srivastava, S. S.: Atmospheric formic and acetic acids: An overview, Rev. Geophys., 37 , 227-248, 1999.

Kirstine, W., Galbally, I., Ye, Y., and Hooper, M.: Emissions of volatile organic compounds (primarily oxygenated species) from pasture, J. Geophys. Res., 103, 10605-10609, 1998.

Lee, A., Schade, G. W., Holzinger, R., and Goldstein, A. H.: A comparison of new measurements of total monoterpene flux with improved measurements of speciated monoterpene flux, Atmos. Chem. Phys., 5, 505-513, 2005,

http://www.atmos-chem-phys.net/5/505/2005/.

Lee, B. H., Munger, J. W., Wofsy, S. C., and Goldstein, A. H.: Anthropogenic emissions of nonmethane hydrocarbons in the northeastern United States: Measured seasonal variations from 1992-1996 and 1999-2001, J. Geophys. Res., 111, D20307, doi:10.1029/2005JD006172, 2006.

Lindinger, W., Hansel, A., and Jordan, A.: Proton-transfer-reaction mass spectrometry (PTR-MS): on-line monitoring of volatile organic compounds at pptv levels, Chem. Soc. Rev., 27, 347-354, 1998.

Lobert, J. M., Scharffe, D. H., Hao, W. M., and Crutzen, P. J.: Importance of biomass burning in the atmospheric budgets of nitrogen-containing gases, Nature, 346, 552-554, 1990.

Lough, G. C., Schauer, J. J., Lonneman, W. A., and Allen, M. K.: Summer and winter nonmethane hydrocarbon emissions from on-road motor vehicles in the midwestern United States, J. Air Waste Manage., 55, 629-646, 2005.

MacDonald, R. C. and Fall, R.: Detection of substantial emissions of methanol from plants to the atmosphere, Atmos. Environ., 27, 1709-1713, 1993.

McKenna, D., Hord, C., and Kent, J.: Hydroxyl radical concentrations and Kuwait oil fire emission rates for March 1991, J. Geophys. Res., 100, 26005-26025, 1995.

Madronich, S., and Calvert, J. G.: Permutation reactions of organic peroxy radicals in the troposphere, J. Geophys. Res., 95, 56975717, 1990.

Mao, H., Talbot, R., Nielsen, C., and Sive, B.: Controls on methanol and acetone in marine and continental atmospheres, Geophys. Res. Lett., 33, L02803, doi:10.1029/2005GL024810, 2006.

Nemecek-Marshal, M., MacDonald, R. C., Franzen, J. J., Wojciechowski, C. L., and Fall, R.: Methanol emission from leaves: Enzymatic detection of gas-phase methanol and relation of methanol fluxes to stomatal conductance and leaf development, Plant Physiol., 108, 1359-1368, 1995.

Nguyen, H. T., Kim, K.-H., and Kim, M.-Y.: Volatile organic compounds at an urban monitoring station in Korea, J. Hazard. Mater., 161, 163-174, 2009.

Park, R. J., Jacob, D. J., and Logan, J. A.: Fire and biofuel contributions to annual mean aerosol mass concentrations in the United States, Atmos. Envrion., 41, 7389-7400, 2007.

Penkett, S. A., Blake, N. J., Lightman, P., Marsh, A. R. W., Anwyl, P., and Butcher, G.: The seasonal variation of nonmethane hydrocarbons in the free troposphere over the North Atlantic Ocean: Possible evidence for extensive reaction of hydrocarbons with the nitrate radical, J. Geophys. Res., 98, 2865-2885, 1993.

Qin, Y., Walk, T., Gary, R., Yao, X., and Elles, S.: $\mathrm{C}_{2}-\mathrm{C}_{10}$ nonmethane hydrocarbons measured in Dallas, USA - Seasonal trends and diurnal characteristics, Atmos. Environ., 41, 60186032, 2007.

Reiss, R.: Temporal trends and weekend-weekday differences for benzene and 1,3-butadiene in Houston, Texas, Atmos. Environ., 40, 4711-4724, 2006.

Roberts, J. M., Fehsenfeld, F. C., Liu, S. C., Bollinger, M. J., Hahn, C., Albritton, D. L., and Sievers, R. E.: Measurements of aromatic hydrocarbon ratios and $\mathrm{NO}_{\mathrm{x}}$ concentrations in the rural troposphere: Observation of air mass photochemical aging and $\mathrm{NO}_{\mathrm{x}}$ removal, Atmos. Environ., 18, 2421-2432, 1984.

Rosado-Reyes, C. M. and Francisco, J. S.: Atmospheric oxidation pathways of acetic acid, J. Phys. Chem. A, 110, 4419-4433, 2006.

Salisbury, G., Williams, J., Holzinger, R., Gros, V., Mihalopoulos, N., Vrekoussis, M., Sarda-Esteve, R., Berresheim, H., von Kuhlmann, R., Lawrence, M., and Lelieveld, J.: Ground-based PTR-MS measurements of reactive organic compounds during the MINOS campaign in Crete, July-August 2001, Atmos. Chem. Phys., 3, 925-940, 2003,

http://www.atmos-chem-phys.net/3/925/2003/.

Sanhueza, E. and Andreae, M. O.: Emission of formic and acetic acids from tropical savanna soils, Geophys. Res. Lett., 18, 17071710, 1991.

Sanhueza, E., Figueroa, L., and Santana, M.: Atmospheric formic and acetic acids in Venezuela, Atmos. Environ., 30, 1861-1873, 1996.

Sanhueza, E., Holzinger, R., Kleiss, B., Donoso, L., and Crutzen, P. J.: New insights in the global cycle of acetonitrile: release from the ocean and dry deposition in the tropical savanna of Venezuela, Atmos. Chem. Phys., 4, 275-280, 2004, http://www.atmos-chem-phys.net/4/275/2004/.

Schade, G. W., and Goldstein, A. H.: Fluxes of oxygenated volatile organic compounds from a ponderosa pine plantation, J. Geophys. Res., 106, 3111-3123, 2001.

Schade, G. W., and Goldstein, A. H.: Seasonal measurements of acetone and methanol: Abundances and implications for atmospheric budgets, Global Biogeochem. Cy., 20, GB1011, doi:10.1029/2005GB002566, 2006.

Schnitzhofer, R., Beauchamp, J., Dunkl, J., Wisthaler, A., Weber, A., and Hansel, A.: Long-term measurements of $\mathrm{CO}, \mathrm{NO}, \mathrm{NO}_{2}$, benzene, toluene and $\mathrm{PM}_{10}$ at a motorway location in an Austrian valley, Atmos. Environ. 42, 1012-1024, 2008.

Seinfeld, J. H. and Pandis, S. N.: Atmospheric Chemistry and 
Physics: From Air Pollution to Climate Change, J. Wiley, New York, USA, 1297-1306, 1998.

Simmonds, P. G., Manning, A. J., Cunnold, D. M., McCulloch, A., O’Doherty, S., Derwent, R. G., Krummel, P. B., Fraser, P. J., Dunse, B., Porter, L. W., Wang, R. H. J., Greally, B. R., Miller, B. R., Salameh, P., Weiss, R. F., and Prinn, R. G.: Global trends, seasonal cycles, and European emissions of dichloromethane, trichloroethene, and tetrachloroethene from the AGAGE observations at Mace Head, Ireland, and Cape Grim, Tasmania, J. Geophys. Res., 111, D18304, doi:10.1029/2006JD007082, 2006.

Singh, H. B., O'Hara, D., Herlth, D., Sachse, W., Blake, D. R., Bradshaw, J. D., Kanakidou, M., and Crutzen, P. J.: Acetone in the atmosphere: distribution, sources, and sinks, J. Geophys. Res., 99, 1805-1819, 1994.

Singh, H. B., Kanakidou, M., Crutzen, P. J., and Jacob, D. J.: High concentrations and photochemical fate of oxygenated hydrocarbons in the global atmosphere, Nature, 378, 50-54, 1995.

Singh, H., Chen, Y., Tabazadeh, A, et al.: Distribution and fate of selected oxygenated organic species in the troposphere and lower stratosphere over the Atlantic, J. Geophys. Res., 103, 37953805, 2000.

Singh, H. B., Salas, L., Herlth, D., Kolyer, R., Czech, E., Viezee, W., Li, Q., Jacob, D. J., Blake, D., Sachse, G., Harward, C. N., Fuelberg, H., Kiley, C. M., Zhao, Y. J., and Kondo, Y.: In-situ measurements of $\mathrm{HCN}$ and $\mathrm{CH}_{3} \mathrm{CN}$ over the Pacific Ocean: Sources, sinks, and budgets, J. Geophys. Res., 108, 8795, doi:10.1029/2002JD003006, 2003.

Sive, B. C., Zhou, Y., Troop, D., Li, Y., Little, W., Wingenter, O. W., Russo, R. S., Varner, R. K., and Talbot, R. W.: Development of a cryogen-free concentration system for measurements of volatile organic compounds, Anal. Chem., 77, 6989-6998, 2005.

Sive, B. C., Varner, R. K., Mao, H., Blake, D. R., Wingenter, O. W., and Talbot, R.: A large terrestrial source of methyl iodide, Geophys. Res. Lett., 34, L17808, doi:10.1029/2007GL030528, 2007.

Solberg, S., Dye, C., Walker, S.-E., and Simpson, D.: Long-term measurements and model calculations of formaldehyde at rural European monitoring sites, Atmos. Environ., 35, 195-207, 2001.

Steeghs, M., Bais, H. P., de Gouw, J., Goldan, P., Kuster, W., Northway, M., Fall, R., and Vivanco, J. M.: Proton-transfer-reaction mass spectrometry as a new tool for real time analysis of rootsecreted volatile organic compounds in Arabidopsis, Plant Physiol., 135, 47-58, 2004.

Stroud, C. A., Roberts, J. M., Williams, E. J., Hereid, D., Angevine, W. M., Fehsenfeld, F. C., Wisthaler, A., Hansel, A., MartinezHarder, M., Harder, H., Brune, W. H., Hoenninger, G., Stutz, J., and White, A. B.: Nighttime isoprene trends at an urban forested site during the 1999 Southern Oxidant Study, J. Geophys. Res., 107, 4291, 10.1029/2001JD000959, 2002.

Talbot, R. W., Beecher, K. M., Harris, R. C., and Cofer III, W. R.: Atmospheric geochemistry of formic and acetic acids at a midlatitude temperate site, J. Geophys. Res., 93, 1638-1652, 1988.

Talbot, R. W., Andreae, M. O., Berresheim, H., Jacob, D. J., and Beecher, K. M.: Sources and sinks of formic, acetic, and pyruvic acids over central Amazonia, 2, Wet season, J. Geophys. Res., 95, 16799-16811, 1990.

Talbot, R. W., Mosher, B. W., Heikes, B. G., Jacob, D. J., Munger, B. C., Daube, B. C., Keene, W. C., Maben, J. R., and Artz, R. S. J.: Carboxylic acids in the rural continental atmosphere over the eastern United States during the Shenandoah Cloud and Photochemistry Experiment, J. Geophys. Res. 100, 9335-9343, 1995.

Talbot, R. W., Dibb, J. E., Scheuer, E. M., Blake, D. R., Blake, N. J., Gregory, G. L., Sachse, G. W., Bradshaw, J. D., Sandholm, S. T., and Singh, H. B.: Influence of biomass combustion emissions on the distribution of acidic trace gases over the southern Pacific basin during austral springtime, J. Geophys. Res. 104, 5623-5634, 1999.

Talbot, R., Mao, H., and Sive, B.: Diurnal characteristics of surface level $\mathrm{O}_{3}$ and other important trace gases in New England, J. Geophys. Res., 110, D09307, doi:10.1029/2004JD005449, 2005.

Tani, A., Hayward, S., and Hewitt, C. N.: Measurement of monoterpenes and related compounds by proton transfer reaction-mass spectrometry (PTR-MS), Int. J. Mass Spectrom., 223, 561-578, 2003.

Thijsse, T. R., Roemer, M. G. M., and van Oss, R. F.: Trends in large-scale VOC concentrations in the Southern Netherlands between 1991 and 1997, Atmos. Environ., 33, 3803-3812, 1999.

US Environmental Protection Agency: 1999 National Emission Inventory Documentation and Data - Final Version 3.0, available at: http://www.epa.gov/ttn/chief/net/1999inventory.html, 1999.

Varner, R. K., Zhou, Y., Russo, R. S., Wingenter, O. W., Atlas, E., Stroud, C., Mao, H., Talbot, R., and Sive, B C.: Controls on atmospheric chloroiodomethane $\left(\mathrm{CH}_{2} \mathrm{CII}\right)$ in marine environments, J. Geophys. Res., 113, D10303, doi:10.1029/2007JD008889, 2008.

Warneke, C. and de Gouw, J. A.: Organic trace gas composition of the marine boundary layer over the northwest Indian Ocean in April 2000, Atmos. Environ., 35, 5923-5933, 2001.

Warneke, C., de Gouw, J. A., Goldan, P. D., Kuster, W. C., Williams, E. J., Lerner, B. M., Jakoubek, R., Brown, S. S., Stark, H., Aldener, M., Ravishankara, A. R., Roberts, J. M., Marchewka, M., Bertman, S., Sueper, D. T., McKeen, S. A., Meagher, J. F., and Fehsenfeld, F. C.: Comparison of daytime and nighttime oxidation of biogenic and anthropogenic VOCs along the New England coast in summer during New England Air Quality Study 2002, J. Geophys. Res., 109, D10309, doi:10.1029/2003JD004424, 2004.

White, M., Russo, R., Zhou, Y., Mao, H., Varner, R. K., Ambrose, J. L., Veres, P., Wingenter, O. W., Haase, K., Stutz, J., Talbot, R. W., and Sive, B.: Volatile Organic Compounds in Northern New England Marine and Continental Environments during the ICARTT 2004 Campaign, J. Geophys. Res., 113, D08S90, doi:10.1029/2007JD009161, 2008a.

White, M. L., Russo, R. S., Zhou, Y., Ambrose, J. L., Haase, K., Frinak, E. K., Varner, R. K., Wingenter, O. W., Mao, H., Talbot, R., and Sive, B. C.: Are biogenic emissions a significant source of summertime atmospheric toluene in rural northeastern United States?, Atmos Chem Phys Discuss., 8, 12283-12311, 2008 b.

Williams, J., Holzinger, R., Gros, V., Xu, X., Atlas, E., and Wallace, D. W. R.: Measurements of organic species in air and seawater from the tropical Atlantic, Geophys. Res. Lett., 31, L23S06, 10.1029/2004GL020012, 2004.

Wisthaler, A., Hansel, A., Dickerson, R. R., and Crutzen, P. J.: Organic trace gas measurements by PTR-MS during INDOEX 1999, J. Geophys. Res., 107, 8024, 10.1029/2001JD000576, 2002.

Yang, K.-L., Ting, C.-C., Wang, J.-L., Wingenter, O. W., Chan, C.C.: Diurnal and seasonal cycles of ozone precursors observed 
from continuous measurement at an urban site in Taiwan, Atmos. Environ., 39, 2829-2838, 2005.

Zhou, Y., Varner, R. K., Russo, R. S., Wingenter, O. W., Haase, K. B., Talbot, R. W., and Sive, B. C.: Coastal water source of shortlived marine halocarbons in New England, J. Geophys. Res., 110, D21302, doi:10.1029/2004JD005603, 2005.
Zhou, Y., Mao, H., Russo, R. S., Blake, D. R., Wingenter, O. W., Haase, K. B., Ambrose, J., Varner, R. K., Talbot, R., and Sive, B. C.: Bromoform and dibromomethane measurements in the seacoast region of New Hampshire, 2002-2004, J. Geophys. Res., 113, D08305, doi:10.1029/2007JD009103, 2008. 